\title{
Historia de dos palacios y una ciudad: Valencia, 1238-1460
}

\author{
Amadeo SerRa Desfilis \\ Universitat de València \\ amadeo.serra@uv.es
}

\begin{abstract}
RESUMEN
Este artículo estudia las relaciones entre el palacio del Real (Palau del Real), la residencia de los reyes de Aragón en Valencia y la Casa de la Ciudad (Casa de la Ciutat o Sala del Consell) desde la conquista cristiana hasta el final del reinado de Alfonso V el Magnánimo. Durante dos siglos la corte real y el gobierno de la ciudad manifestaron la alianza, la rivalidad y los conflictos a través de la arquitectura y la decoración de sus respectivas sedes. Los emplazamientos, las grandes salas, las capillas con reliquias y las fiestas cívicas desempeñaron un papel notable como instrumentos al servicio tanto de los reyes y sus oficiales como de los consejeros municipales. Aunque ambos palacios fueron derribados en el siglo XIX, las fuentes archivísticas y literarias atestiguan ampliamente cómo los artistas y los modelos se intercambiaron y cómo se fomentó y desplegó la innovación en estos magníficos escenarios de poder y decoro.
\end{abstract}

Palabras clave: Corte, urbanismo, palacios, fiesta cívica, arquitectura tardogótica.

\section{A tale of two palaces and a city: Valencia, 1238-1460}

\begin{abstract}
This article studies relations between Real palace (Palau del Real), the royal residence of Aragonese kings in Valencia, and the City Hall (Casa de la Ciutat o Sala del Consell) since the Christian conquest till the end of Alfonso V the Magnanimous' reign. During two centuries royal court and city government expressed alliance, rivalry and conflicts through architecture and decoration of their respective head offices. Building sites, great halls, chapels with relics and civic festivals played a remarkable role as instruments at the service of either kings and their officials or municipal councilors. Although both palaces were demolished in $19^{\text {th }}$ century, archival and literary sources attest widely how artists and models were exchanged and innovation was fostered and displayed in these magnificent sceneries of power and decorum.
\end{abstract}

Key words: Court, town planning, palaces, civic festival, late gothic architecture. 
El asiento y la representación del poder en la escena urbana es un tema destacado en la historia de la ciudad medieval. La sede episcopal que podía remontarse a los orígenes de la civitas en la baja Antigüedad tuvo que convivir desde los siglos centrales de la Edad Media con la corte real o señorial y, más tarde, con el gobierno municipal cuando éste dispuso de un lugar de reunión estable y propio. En las ciudades europeas con mayor autonomía y madurez institucional, como las italianas o en los antiguos Países Bajos, los palacios cívicos rivalizaron cuando no suplantaron en el prestigio de sus emplazamientos y la magnificencia del ornato a la residencia del poder real o al palacio episcopal ${ }^{1}$. En la Corona de Aragón, donde el término palau solía reservarse para el que habitaba el obispo o la residencia real, las instituciones de gobierno municipal se dotaron de sedes permanentes y representativas de un poder emergente en la escena urbana. La movilidad de la corte real y la presencia discreta de los palacios episcopales levantados a la sombra de las catedrales despejaron el campo para la arquitectura civil, que definió el prestigio y la identidad de cada una de las ciudades, reflejando al mismo tiempo un ideal de fasto inspirado en la vida cortesana.

La construcción o la renovación de las sedes del poder civil, de los espacios del comercio y de los servicios públicos se convirtieron en un capítulo fundamental de la política urbana de los gobiernos municipales y de la monarquía, que invirtieron grandes sumas y notables recursos técnicos en la materialización de estos proyectos. Los ediles se miraron en el espejo de los monarcas, los emularon y procuraron afirmar la posición de su ciudad frente a otras con las que compartían príncipe y en el contexto internacional de las redes comerciales y las relaciones diplomáticas. En este aspecto, el caso valenciano reviste un interés especial por la reorganización de la ciudad tras la conquista cristiana, la tardía pero vigorosa afirmación del poder municipal y la

1 Un panorama que abarca bibliografía y fuentes, sobre todo italianas, en A. GROHMANN, "L'edilizia e la città. Storiografia e fonti", S. CAVACIOCCHI (ed.), L'edilizia pirma della Rivoluzione Industriale. Secc. XIII-XVIII. Atti della Tentraseisesima Settimana di Studi, 26-30 aprile 2004, Firenze, 2005, pp. 109-136; para las obras públicas de una gran ciudad medieval del norte de Europa como Brujas cabe citar el libro clásico de J.P. SOSSON, Les travaux publics de la ville de Bruges, XIVe-XVe siècles. Les matériaux, les hommes, Bruxelles, 1977; algunas monografías sobre ciudades italianas se deben a R. GOLDTHWAITE, The Building of Renaissance Florence: an Economic and Social History, Baltimore, 1980; y "Il contesto economico del palazzo florentino nel Rinascimento. Investimento, cantiere, consumi”, Annali di architettura, 2 (1990), pp. 53-58; P. BOUCHERON, Le pouvoir de bâtir. Urbanisme et politique édilitaire à Milan (XIV-XVe siècles), Rome, 1998 analiza la actividad constructiva patrocinada por los Visconti y los Sforza en Milán en los siglos XIV y XV; G. VILLA, Siena medievale. La costruzione della città nell'eta “Ghibellina”, 1200-1270, Roma, 2004; L. W. PARTRIDGE, Arts of Power. Three Halls of State in Italy, 1300-1600, Los Angeles, 1992, que compara los ejemplos de Siena, Mantua y Florencia en tres momentos sucesivos. Acerca de los antiguos Países Bajos véase M. BUYLE et alii., Architecture gothique en Belgique, Tielt, 1997; W. PARAVICINI, "Die Residenzen der Herzöge von Burgund, 1363-1477”, H. PARZE y W. PARAVICINI (eds.), Furstliche Residenzen im spätmittelalterlichen Europa, Sigmaringen, 1991, pp. 207-263, reeditado en Menschen am Hof der Herzöge von Burgund: Gesammelte Aufsätze, Stuttgart, 2002; S. JUGIE y S.N. FLIEGEL (eds.), Art from the Court of Burgundy. The Patronage of Philip the Bold and John the Fearless, Cleveland, 2004, pp. 137163; acerca del Imperio, W. PARAVICINI, J. HIRSCHBIEGEL y J. WETTLAUFER, Höfe und Residenzen im spätmittelalterlichen Reich, Ostfildern, 2007. Sobre Francia, véase A. SALAMAGNE (ed.), Le palais et son décor au temps de Jean de Berry, Tours, 2010; una visión europea reciente sobre el problema aquí tratado para Valencia en W. PARAVICINI y J. WETTLAUFER (eds.), Der Hof und die Stadt: Konfrontation, Koexistenz und Integration in Spätmittelalter und Früher Neuzeit: 9. Symposium der Residenzen-Kommission der Akademie der Wissenschaften zu Göttingen, Halle an der Saale, 25-28 September 2004, Ostfildern, 2006. 
poco disimulada ambición de sus regidores por que se convirtiera en centro político y financiero de la Corona de Aragón en tiempos de Alfonso el Magnánimo y sus sucesores. Y aunque ninguna de las sedes del poder local en la Edad Media se conserva en pie, suplen esta carencia los ricos fondos documentales, que abarcan desde los ceremoniales a los libros de fábrica o la contabilidad pasando por la correspondencia, y la noticia figurada o escrita de cómo fueron estos vetustos y al tiempo solemnes edificios, aparte de las reliquias que la arqueología o el aprecio de las antigüedades han traído hasta nuestros días ${ }^{2}$. A través de todos estos testimonios y del conocimiento sobre la fábrica de estos palacios y el decoro de sus interiores es posible estudiar el diálogo entablado entre el Real y la Casa de la Ciudad como centros y escenarios de la monarquía y el municipio respectivamente.

\section{La conquista y la elección de la sedes del poder}

Los musulmanes tuvieron unos días de plazo para abandonar la ciudad antes de que el 9 de octubre de 1238 el rey Jaime I y sus tropas entraran solemnemente en Valencia en una cabalgata triunfal que culminaría con un Te Deum en la mezquita aljama, consagrada ese mismo día como catedral cristiana. La ciudad, con sus casas, las murallas, la huerta, las alquerías y la red de acequias aparecieron a los ojos de los conquistadores como un formidable botín que había venido repartiéndose desde hacía algún tiempo y convenía ahora administrar con tiento. El Llibre del Repartiment del Archivo de la Corona de Aragón ofrece una foto fija de este proceso que fue seguramente mucho más dinámico y articulado, pues se trataba de instaurar un sistema de nuevos vínculos sociales importados por los colonos cristianos y, con el tiempo, de referencias también nuevas y cristianas en un espacio urbano de neta impronta islámica ${ }^{3}$. Tras impulsar y sostener la empresa de la conquista, la monarquía puso en pie una diócesis y un reino que aún tardarían en alcanzar su plenitud institucional. El municipio, aunque estaba llamado a ser el principal agente urbano desde mediados del siglo XIV, necesitó tiempo para definir sus competencias y sobre todo robustecer

2 Sobre el palacio del Real, véase, principalmente J. BÉRCHEZ y M. GÓMEZ-FERRER, "El Real de Valencia en sus imágenes arquitectónicas", Reales Sitios, 158 (2003), pp. 33-47; L. ARCINIEGA, "Construcción, usos y visiones del Palacio Real de Valencia bajo los Borbones", Archivo de Arte Valenciano, 85 (2005), pp. 21-39; J.V. BOIRA (ed.), El Palacio Real de Valencia. Los planos de Manuel Cavallero (1802), Valencia, 2006; L. ARCINIEGA, "Construcciones, usos y visiones del Palacio Real de Valencia bajo los Austrias", Ars longa, 14-15 (2005-2006), pp. 129-164; A. SERRA DESFILIS, "Cort e palau de Rey. The Real Palace of Valencia in the medieval ages", Imago temporis. Medium Aevum, 1 (2007), pp. 121-148; y M. GÓMEZ-FERRER, El Real de Valencia (1238-1810), Valencia, 2012. A propósito de la Casa de la Ciudad, L. TRAMOYERES BLASCO, "Los artesonados de la antigua Casa Municipal de Valencia", Archivo de Arte Valenciano, III (1917), pp. 31-71; A.SERRA DESFILIS, "El fasto del palacio inacabado. La Casa de la Ciudad de Valencia en los siglos XIV y XV", en F. TABERNER (ed.), Historia de la ciudad III: Arquitectura $y$ transformación urbana en la ciudad de Valencia, Valencia, 2004, p. 73-99; F. IBORRA BERNAD, La Casa de la Ciudad de Valencia y el Palacio de Mosén Sorell. De la memoria nostálgica a la reivindicación arquitectónica de dos episodios perdidos del Siglo de Oro valenciano, tesis doctoral inédita, Universidad Politécnica de Valencia, 2012.

3 Llibre del Repartiment de València, A. FERRANDO (ed.), Valencia, 1984. 
su autoridad si quería llevar a cabo su propio programa. El rey había conquistado la ciudad, la dividió entre sus fieles y aquellos cuya voluntad quería ganarse, y adoptó las medidas decisivas para reorganizar el espacio urbano. Aparte del asentamiento de la red de iglesias y conventos, los fueros y privilegios reales respondieron a la coyuntura de la colonización de la ciudad mientras se configuraba un sistema de gobierno municipal.

Un cúmulo no desdeñable de circunstancias aceleró el ritmo de las transformaciones urbanas hacia mediados del siglo XIV. Poco a poco, Valencia dejó de ser la ciudad fronteriza que había acogido a las primeras oleadas de colonos, pues se había integrado en el sistema urbano de la Corona de Aragón, claramente orientado hacia la expansión mediterránea desde tiempos de Pedro III el Grande, y la amenaza musulmana parecía ahora más lejana y desde luego menos intimidatoria tras la victoria del Salado (1340). Los peligros y las dificultades no iban a faltar en la segunda mitad del Trescientos, pero la ciudad se mostraría capaz de superarlos de manera que salió fortalecida de todas estas pruebas. Si la Peste Negra acarreó un freno al crecimiento urbano en gran parte de Europa, Valencia pudo sin embargo compensarlos con la inmigración de gentes atraídas por las oportunidades de una ciudad dinámica aun bajo el azote de las epidemias de 1348, 1362, 1374-1375, 1380, 1383-1384, 1395 (lo temps de les grans mortaldats) y, precisamente a causa de ellas, necesitada de nuevos contingentes demográficos. La revuelta de la Unión (1347-1348), encabezada por la ciudad de Valencia, supuso una grave crisis en la que se dirimieron los conflictos de intereses entre el municipio y la autoridad monárquica coincidiendo con la primera gran epidemia, la sobrecarga fiscal y el azote del hambre y la carestía ${ }^{4}$. La derrota de los unionistas recortó los privilegios de la ciudad, que quedó sometida a la corona, pero no frenó del todo la consolidación de sus instituciones. La guerra con Castilla (1356-1375) brindó la ocasión para que se restaurasen los vínculos de apoyo mutuo entre Valencia y el vencedor del conflicto la Unión, Pedro IV el Ceremonioso, quien se mostró agradecido con el papel de la ciudad en el esfuerzo bélico.



Fig. 1. Dibujo para la vista de Valencia desde el Norte, Anthonie van den Wijngaerde, 1563. (Viena, Österreichische Nationalbibliothek, Cod. Min. 41, f. 18).

4 M. RODRIGO LIZONDO, “La Unión valenciana y sus protagonistas”, Ligarzas, 7 (1975), pp. 133-166. 
El Real valenciano debía ser residencia temporal de una corte itinerante y representar a la vez el poder real en la ciudad. Como sede cortesana debía estar a punto para cada visita real; como imagen arquitectónica de la Corona tenía que mostrar una prestancia monumental, un cierto fasto en su interior y se esperaba que acogiera las funciones administrativas reales y sirviera de escenario a un ceremonial magnífico que distinguiera las recepciones de la realeza. Estas múltiples demandas marcarían el proceso constructivo y la configuración del edificio. En primer término por la necesidad de convertir una antigua almunia islámica en un palacio cristiano comparable a las residencias de la corte en otras ciudades de la Corona de Aragón; luego por las intervenciones que obedecían a las visitas y estancias del monarca y su familia; en fin, porque los períodos de robustecimiento del poder real coincidieron con las intervenciones más decisivas en la configuración del edificio (reinados de Jaime II, 1292-1327; Pedro IV el Ceremonioso, 1336-1387 y Alfonso el Magnánimo, 14161458). El último reinado marca el otro vector de la trayectoria arquitectónica del Real bajomedieval: definir la imagen del poder monárquico que se mostraba ante la ciudad de Valencia.

Cuando Jaime I conquistó la ciudad de Valencia renunció a ocupar el alcázar de los reyes musulmanes, aunque en torno a él se situarían los centros de poder de la nueva ciudad cristiana como el palacio episcopal, la catedral y la primera sede del gobierno municipal, escogiendo como lugar de residencia temporal la almunia o quinta de recreo que los mismos reyes de taifa habían levantado al otro lado del río, fuera del recinto amurallado. No había actuado así el Cid cuando conquistó Valencia, pues asentó su efímero poder en el alcázar islámico, como atestigua la Primera Crónica $\mathrm{General}^{5}$. A tenor de las excavaciones arqueológicas y de las fuentes escritas, el recinto del alcázar valenciano debía de formar más bien un conjunto de casas con patios, albercas y un cementerio real que un edificio compacto y bien delimitado del entorno urbano, donde se asentaban la catedral, el palacio episcopal y el almudín ${ }^{6}$.

La decisión de Jaime I puede compararse con la que el propio monarca y sus predecesores habían adoptado al tomar posesión de otras capitales de antiguo dominio islámico como Lérida, Zaragoza o Tortosa. En todos los casos se trató de adaptar una residencia separada del núcleo urbano como palacio de los reyes cristianos que a partir de entonces gobernarían estas ciudades. En Valencia, hubo quizá razones simbólicas, pues el Llano del Real había sido escenario de las negociaciones que condujeron a la rendición musulmana en 1238, y porque el traslado de la sede principal del poder marcaba una nueva época, como la temprana puesta de la primera piedra de la catedral en 1262. Además, el emplazamiento del Real tenía ventajas prácticas como el dominio visual desde la orilla norte del Turia de una ciudad recién conquistada, la oportuna posición defensiva, la disponibilidad de terrenos para su ampliación y reforma en el futuro y, sobre todo, los huertos y jardines que convertirían este sector en un paisaje grato y cómodo para una residencia real. El lugar no era tanto el solar de un

5 El Cid dijo a los representantes de la aljama que ocuparía el alcázar: "En tal manera que la mi morada sea dentro en la villa, en el alcaçar, et que los míos cristianos tengan todas las fortalezas de la cibdat", véase Primera Crónica General, R. MENÉNDEZ PIDAL (ed.), Madrid, 1906, capítulos 919-920, pp. 590-591.

6 J. PASCUAL PACHECO y J. VIOQUE HELLÍN, El alcázar islámico de Valencia, Valencia, 2010. 
palacio como una extensión de terreno fértil y bien regado, que le daría el nombre de El Real todavía recordado, con vistas preferentes hacia la ciudad amurallada, la vega del río y el mar en lontananza ${ }^{7}$. Basándose en el testimonio de las fuentes coetáneas, como la crónica de Jaime I, José María Zacarés se refirió a la Casa del rey musulmán Lobo, en la calle de San Jaime, entre la plaza de Manises y la pequeña plaza de Figuereta como el lugar donde pudo habitar el rey don Jaime hasta que las obras del Real estuvieron acabadas ${ }^{8}$.

Es probable que las obras fueran al principio más bien modestas y no pasaran del establecimiento de una capilla y la adaptación de salas y estancias para las funciones residenciales y de representación más necesarias. En otras palabras, un cambio de usos sólo relativo respecto del que había tenido la almunia islámica y sujeto en lo sucesivo a la frecuencia y duración de las estancias de los reyes y su familia en la ciudad y a la voluntad de mostrar la majestad del monarca en un espacio propio. Cuando Alfonso X el Sabio se detuvo en Valencia camino del concilio de Lyon, sólo el monarca castellano pudo hospedarse en el Real mientras que los infantes y la mayor parte de su séquito encontraron acomodo en otras casas de la ciudad ${ }^{9}$. Sin embargo, las obras no se hicieron esperar y Pedro III el Grande ya realizó trabajos de cierta importancia en la década de 1280, bajo la supervisión del judío valenciano Vives aben Vives, preparando la estancia de su esposa, Constanza de Sicilia; su sucesor Alfonso III el Benigno anhelaba verlo todo dispuesto para su llegada a la ciudad en 1286 y dos años más tarde instaba al Baile general, Bernat Guillem Català, a concluir la obra nueva del Real ${ }^{10}$.

Por entonces los reyes de la Corona de Aragón tenían una corte ambulante que les acompañaba allí donde fuera conveniente su presencia y necesitaban residencias adecuadas en todas las capitales de sus estados: la Almudaina de Mallorca, las Zudas de Huesca y Lérida, la Aljafería de Zaragoza, el Palacio Real de Barcelona, el castillo del Rey de Tarragona son las mejor conocidas ${ }^{11}$. El Real de Valencia tuvo en común con algunas de ellas, además del emplazamiento cercano al núcleo urbano, la impronta de la tradición islámica en sus espacios y la decoración, incluso después de la conquista cristiana, pues artífices mudéjares trabajaron en el Real valenciano desde fines del siglo XIII. Cada uno de los palacios, además, debía responder en cierto modo a la identidad particular del territorio donde se asentaba el poder del monarca y, en

\footnotetext{
7 El equívoco entre el adjetivo "real" aplicado a la residencia de los monarcas y el sustantivo "Real", derivado del árabe rahal, perdura hasta nuestros días, pero las fuentes históricas, empezando por el Llibre del Repartiment y la crónica de Jaime I no dejan lugar a dudas: el palacio y el su entorno se llamaron del Real. Véase la exposición de Roque Chabás del manuscrito de 1767 en J.TEIXIDOR, Antigüedades de Valencia, R. CHABÁS (ed.), Valencia, 1895, I, pp. 437-439.

8 J.M.Z. [J. M". ZACARÉS], "Casa-palacio del Rey D. Jaime”, El Fénix. Semanario valenciano de literatura, artes, historia, teatros, etc., 29 (20 de abril de 1845), pp. 151-152.

9 J. RUBIÓ BALAGUER, Vida española en época gótica, $2^{\mathrm{a}}$ ed. Barcelona, 1985, p. 83.

10 J.M. ORTIZ, Descubrimientos de las leyes palatinas y derechos que tiene Vuestra Majestad como Rey de Aragón en vuestro Palacio Real de Valencia, Madrid, 1782; y L. FULLANA, "El Palau del Real", Cultura Valenciana, 1 (1926), pp. 2-5.

11 F. ESPAÑOL BERTRAN, Els escenaris del rei. Art i monarquia a la Corona d'Aragó, Manresa, 2001, se ocupa de las residencias reales en su conjunto. A.M. ADROER I TASIS, Palaus reials de Catalunya, Barcelona, 2003, ilustra el caso de los palacios de Cataluña y Rosellón.
} 
consecuencia, el Real podía reflejar también cómo entendía la corona sus relaciones con la capital del reino de Valencia.

La pluralidad de centros territoriales en la Corona de Aragón contrastaba con la tendencia centralizadora de otras monarquías europeas en auténticas capitales como Londres, París, Praga o el Aviñón papal durante el siglo XIV, por más que la corte continuara desplazándose. En todo caso el modelo catalano-aragonés corresponde a la itinerant rulership que practicaban emperadores y reyes desde la temprana Edad Media: el rey permanecía durante un tiempo en el centro de un territorio y se relacionaba con sus súbditos y las instituciones locales que le brindaban hospitalidad y homenaje a cambio de su visita y de las oportunidades aparejadas a la presencia del monarca como sujeto del poder. En su ausencia, el palacio actúa como símbolo del poder real, de la continuidad dinástica y de la administración vigilante del monarca a través de sus representantes y agentes, como eran en el caso valenciano, el Lugarteniente general del Reino, el Mestre Racional y el Baile ${ }^{12}$. Esta presencia intermitente del monarca tenía su traducción fiscal en el impuesto de la cena, que se ofrecía en especie como hospitalidad al rey o bien se recaudaba anualmente en cada municipio si no lo había visitado el monarca o el heredero al trono. Pedro III el Grande había estipulado que la corte se trasladara a lo largo del año de un palacio a otro en cada uno de sus reinos, a la manera del iter regis per regna imperial, y durante sus ausencias un hombre de confianza tenía a su cargo la residencia en calidad de custodio ${ }^{13}$. Este cargo se mantendrá en el Real de Valencia y recaerá en una de las personas de confianza del monarca a lo largo del período que nos ocupa. A él corresponderá a menudo supervisar la buena marcha de las obras, que administra en sus cuentas el Mestre Racional como intendente de la hacienda real.

Por otra parte, era común que las residencias reales asentadas en antiguas fortificaciones tuvieran una situación periférica que podía favorecer su defensa en caso de ataque enemigo y ante la población urbana vecina: París en tiempos de Carlos V disponía de uno de los sistemas más complejos, con los palacios del Louvre y Vincennes, además de la Bastilla, que protegía el Hotel Saint Pol, como residencia privada del monarca, o el castillo de Praga para los reyes de Bohemia. Alain Salamagne ha subrayado la paradoja de que cuando la guerra era una amenaza patente y la artillería empezaba a imponerse en los asedios, los constructores y sus promotores se esmeraran en la comodidad residencial y el refinamiento decorativo y adaptasen los espacios internos a las exigencias de un articulado ceremonial ${ }^{14}$. De hecho, el Real valenciano estuvo expuesto siempre a ataques enemigos, como el del ejército castellano en 1363, no menos que al riesgo de las inundaciones provocadas por las rápidas crecidas del Turia, como la que afectó al Real en 1427 y que anotó en su diario el capellán

12 E. VOLTMER, "«Palatia » imperiali e mobilità della corte (secoli IX-XIII)”, G. SERGI y E. CASTELNUOVO, Arti e storia nel Medioevo I: Tempi. Spazi. Istituzioni, Torino, 2002, pp. 564-568, aunque se refiere sobre todo al Imperio y a los siglos centrales de la Edad Media; la edición española se publicó como Arte e historia en la Edad Media, Madrid, 2009.

13 L. FULLANA, op. cit., 1926, p. 5.

14 A. SALAMAGNE, op. cit., 2010, pp. 11-15; y "La forfitication et le canon", Du métier des armes à la vie de cour, de la forteresse au chateau de sejour: familles et demeures aux XIVe-XVIe siècles, Turnhout, 2005, pp. 17-35. 
de Alfonso el Magnánimo ${ }^{15}$. A la postre, su situación dio argumentos tácticos a los partidarios de su derribo en 1810, cuando el ejército napoleónico se aproximaba por segunda vez Valencia a las órdenes del mariscal Louis-Gabriel Suchet ${ }^{16}$.

Por privilegio real, las instituciones municipales dispusieron, desde 1239, de una sede propia junto a la mezquita mayor, convertida en catedral ${ }^{17}$. Tras una primera estancia en el entorno del alcázar musulmán, cerca del palacio episcopal y de la catedral, el tribunal del Justicia o cort se trasladó en 1311 a una nueva sede en la calle de las Cortes, al otro lado de la iglesia mayor, en atención a la falta de espacio del antiguo local. Era en un enclave privilegiado, aunque estuviera desprovisto de una plaza ante él que evitara la contemplación esquinada del frente principal. Así ante a la puerta gótica de los Apóstoles de la seo se configuró pronto, al cabo de poco más de un siglo de la conquista cristiana, un centro cívico dominado por la Casa de la Ciudad o Sala del Consell. El edificio aparecía en ángulo tanto para quienes lo contemplaran desde la plaza como para los viandantes que venían desde la calle Caballeros y demás calles vecinas. Carecía de hecho de visibilidad frontal, constreñido como estaba por las relativamente angostas calles de la Bailía al norte, de los Hierros de la Ciudad, al este, Reloj Viejo, al oeste, y la propia de las Cortes, que podía considerarse su acceso preferente desde el sur. También comparecían en ángulo al otro extremo de una plaza pública muchos conjuntos monumentales en otras ciudades del área mediterránea, aunque en Valencia el palacio municipal nunca alcanzó una visualización dominante en el espacio público y quizá por ello -entre otros motivos- fueron sus ambientes interiores los enriquecidos con más esplendor. Las torres que flanqueaban el cuerpo principal del edificio en la calle de las Cortes realzaron la silueta de un inmueble que fue, ante todo, una casa, sometida a sucesivas reformas y obligada a representar el poder cívico de las instituciones que en ella tenían su asiento. Fue incluso un palacio no reconocido como tal, pero se hizo acreedor a tal título por la magnificencia del ornato de sus salas.

\section{El palacio como sede y escenario del poder real}

Los monarcas de la Corona de Aragón tardaron un tiempo en definir la imagen del poder a través de la arquitectura de sus palacios. En un largo proceso que abarca casi todo el siglo XIV fue cambiando la forma de disponer, usar y decorar estos ambientes al compás de la creciente complejidad del ceremonial cortesano, de la ampliación de los séquitos y comitivas que acompañaban a los reyes y de la voluntad de emular a otras casas reales en su sentido de la magnificencia. El predicador valenciano san Vicente Ferrer expresó en uno de sus sermones que cort e palau de rey, requer gran

15 M. MIRALLES, Crònica i dietari del capellà d'Alfons el Magnànim, edición de M. Rodrigo, València, 2011, p. 178.

16 J.V. BOIRA MAIQUES, "Los planos del Palacio Real de 1802: un viaje de Valencia a París hace doscientos años", op. cit., 2006, pp. 13-22.

17 L. ALANYÁ, Aureum Opus regalium privilegiorum civitatis et regni Valentie, Valencia, 1515, privilegio $\mathrm{n}^{\mathrm{o}} 4$ de Jaime I. Sobre los antecedentes y la obra de la Casa de la Ciudad véase A. SERRA DESFILIS, op. cit., 2004, pp. 73-99; y F. IBORRA BERNAD, op. cit., 2012. 
casa en los mismos años en que Francesc Eiximenis glosaba cómo la liberalidad alcanzaba la magnificencia mandando construir
"notables cases e notablement ordenades, axí en hedificis com en gran regiment, e en reebre persones nobles altament. E notes ací alcuns grans doctors que lo príncep magnífich principalmente deu attendre a la obra que attén a fer, que sia alta e bella e noble e feta excel·lentment, que no a la pecunia quanta serà e que deu aver sobre ella gran estudi, pus que sap y és bastante e poderós" ${ }^{\prime 18}$.

Pero las casas que eran al cabo los apartamentos reales debieron también mucho al cuidado de las reinas y en general de las mujeres, madres, esposas, hermanas e hijas de quienes ocuparon sucesivamente el trono, y sus nombres están tan ligados o más que los de los varones a la historia del Real de Valencia.

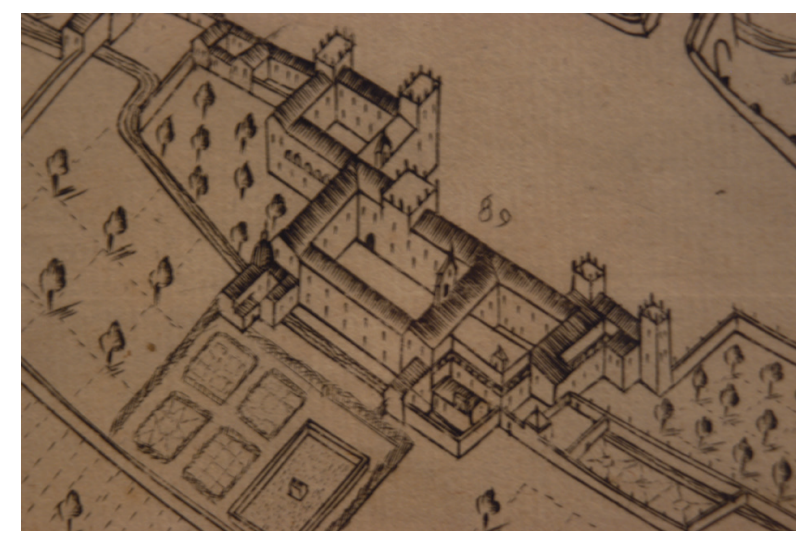

Fig. 2. Detalle del palacio del Real en la vista de Valencia de Antonio Mancelli, 1608 (Valencia, Archivo Histórico Municipal).

Las Ordinacions de cort de 1344, elaboradas a partir del modelo de las Leyes palatinas de Mallorca y de los usos establecidos en la Corona de Aragón desde fines del siglo XIII, definieron el ceremonial de los reyes aragoneses en los siglos venideros y cabe situarlas como parte de un proyecto para organizar la administración y los cargos de la casa real, así como la pompa, las ceremonias y el marco arquitectónico que debían acompañar al monarca ${ }^{19}$. Las ordenanzas de Pedro III el Grande (1277),

18 V. FERRER, Sermons, G. SCHRIB (ed.), Barcelona, 1975, vol. III, sermón LXV p. 81, citado por F. ESPAÑOL BERTRAN, op. cit., 2001, p. 9; F. EIXIMENIS, Dotzé llibre del Crestià, WITTLIN et alii (eds.), Girona, 1986, II, vol. 1 (segona part, volum primer), p. 440.

19 JAUME III de Mallorca, Lleis palatines, L. PÉREZ MARTÍNEZ, et alii (eds.), Palma de Mallorca, 1991; P. BOFARULL Y MASCARÓ, "Gobierno y Casa Real de los Monarcas de Aragón", Colección de Documentos Inéditos del Archivo General de la Corona de Aragón, vols. V y VI, Barcelona, 1850 es la edición histórica; a ella siguieron los trabajos de F. CARRERAS CANDI, "Ordenanzas para la Casa y Corte de los Reyes de Aragón (siglos XIII y XIV), Cultura Española, 2 (1906), pp. 327-338; y "Redreç de la Reyal Casa: 
sancionadas por Jaime II, establecieron ya los principales oficios de la casa real y reservaron para los meses de invierno la estancia de la corte en el Reino de Valencia; a ellas siguieron las promulgadas por Alfonso III el Liberal en 1286, ampliadas por Jaime II el Justo en 1308 con disposiciones complementarias que regulaban el acceso a la persona del monarca. Pedro IV pretendía unificar la imagen y el ceremonial de las residencias reales en todos los territorios de la Corona de Aragón, a los que había reincorporado el Reino de Mallorca, como lo demuestran los encargos artísticos de las capillas reales de retablos a Ferrer Bassa y Ramon Destorrents y las intervenciones llevadas a cabo en las principales residencias como la Aljafería de Zaragoza, los palacios reales de Barcelona, Palma, Perpiñán y Valencia.

\section{La corte y la ciudad en reconstrucción}

Un domingo de abril de 1348 el palacio del Real fue atacado por una multitud de partidarios de la Unión, pese a los intentos por cerrarles las puertas. El propio rey cuenta en su crónica cómo tuvo que hacer frente a los asaltantes que habían entrado en busca de los consejeros roselloneses del monarca. Pedro IV se encontraba en la cámara del Real sobre el portal y tras dejar a la reina en compañía de dos hombres de su confianza, se acercó a la escalera principal para desafiar a los rebeldes maza en mano. Así aplacó la furia de sus vasallos, que le vitorearon, aunque aquella noche una multitud con músicos y bailarines volvieron con ánimo festivo al Real y forzaron al rey y a la reina a bailar, en una humillación que el monarca no olvidó ${ }^{20}$. En aquella ocasión la majestad del rey fue un juguete en manos del pueblo y desaparecieron las distancias entre la corte y la escena urbana que marcaban de distinto modo la topografía y el ceremonial.

Pocos años después, el comienzo de la guerra con Pedro I de Castilla dejó patente la frágil posición defensiva del Real y de toda la ciudad. Por tanto, en 1356 se aceleraron los trabajos para construir un nueva muralla y se propuso que abarcase también el Llano del Real, pero las autoridades municipales prefirieron empezar por el foso y los muros de Valencia, aplazando en varias ocasiones la construcción de las defensas del Real, pues la ciudad soportaba muchos gastos por la construcción de las nuevas fortificaciones ${ }^{21}$. Después de treguas, la guerra se abatió otra vez sobre Valencia en 1362 y en la primavera siguiente la ciudad resistía al asedio de las tropas castellanas

ordenaments de Pere lo Gran e Anfós lo Liberal”, Boletín de la Real Academia de Buenas Letras de Barcelona, IX, no 35 (1909), pp. 97-108; J. URRÍES Y AZARA, "Las ordinaciones de la corte aragonesa en los siglos XIII y XIV”, Boletín de la Real Academia de Buenas Letras de Barcelona, VII (1913-1914), pp. 220-229 y 284-292; la edición más moderna de las ordenanzas de Pedro IV se debe a F. M. GIMENO BLAY et alii (eds.), Ordinacions de la Casa i Cort del Pere el Cerimoniós, Valencia, 2009; y A. BEAUCHAMP, "Ordonnances et réformes de l'hôtel royal au début du règne de Pierre IV d'Aragon", Anuario de Estudios Medievales, 39,2 (2009), pp. 555-573.

20 PERE III EL CERIMONIÒS, Crònica, F. SOLDEVILA (ed.), Les quatre grans cròniques, Barcelona, 1971, pp. 1102-1103.

21 Archivo Municipal de Valencia (en lo sucesivo: AMV). Manual de Consells, A-13, f. 49r (segunda mano), 15 de enero de 1359, pese al acuerdo favorable adoptado el mes de septiembre de 1356 para proteger mejor la residencia del monarca. Véase M.M. CÁRCEL ORTÍ y J. TRENCHS ODENA, "El Consell de 
hasta que Pedro I levantó el sitio el 10 de junio, no sin antes haber ocupado, saqueado e incendiado el Real, expuesto en la ribera norte del Turia. Por entonces el palacio era, en palabras del historiador Jerónimo Zurita,

"una de las más principales casas reales que los reyes tenían en aquellos tiempos, que se llamaba El Real; de donde el rey de Castilla mandó llevar al alcázar a Sevilla unas muy hermosas columnas de jaspe que allí había"22.

No se conoce el alcance de los daños, pero las fuentes narrativas indican que sólo sobrevivió una torre en la que el Rey mandó izar el estandarte capturado a los castellanos cuando liberó Valencia del asedio y consta que el Ceremonioso tenía que residir en el palacio episcopal en $1364^{23}$. Otras fuentes coetáneas aluden, sin embargo, a un banquete celebrado en el Real tras librarse la ciudad del asedio castellano ${ }^{24}$. En todo caso, la reconstrucción se demoró algún tiempo y estuvo precedida por la orden del monarca de impedir que se levantaran edificios de cierta altura en los alrededores de la ciudad con excepción de las torres del Real, para evitar que se repitiera la amenaza desde la orilla izquierda del Turia y, sobre todo, que otras construcciones compitiesen con la residencia del monarca en aquella zona ${ }^{25}$. En 1371, Pedro IV, ocupando todavía la sala principal del palacio episcopal por no disponer del Real, apelaba al Consejo municipal valenciano para que contribuyera a costear las obras argumentando que la nueva residencia animaría a los monarcas a pasar más tiempo en la ciudad y que con ellos llegarían gran número de cortesanos, oficiales, así como forasteros atraídos por celebraciones, como el anunciado torneo entre un caballero inglés y otro francés. La asamblea municipal rechazó la petición instando al monarca a dirigirse a otras ciudades que habían ayudado a los castellanos a incendiar el palacio, pero meses después contribuyó a financiar las obras del palacio de la Reina en Barcelona ${ }^{26}$.

Fue durante el reinado de Pedro IV cuando tomó forma y definitivo asiento la Casa de la Ciudad, conocida también como Sala del Consell. En 1311 el rey Jaime II había permitido que los tribunales del Justicia dejasen el edificio que ya resultaba insuficiente junto a la plaza de la Almoina para trasladarse a las casas compradas a los hermanos Della Volta, que hubo que ampliar y reformar hacia 1340 por necesidades de espacio. En aquella Sala de la cort fue donde tuvo su sede el gobierno de la ciudad durante el conflicto de la Unión y allí se colocó una campana de bronce para convocar

Valencia: disposiciones urbanísticas (siglo XIV)”, La ciudad hispánica de los siglos XI al XVI, Madrid, 1985, vol. II, pp. 1481-1545, en especial, p. 1507.

22 J. ZURITA, Anales de la Corona de Aragón, A. CANELLAS (ed.), Zaragoza, 1978, vol. IV, libro IX, capítulo 45, p. 462.

23 AMV, Manual de Consells, A-14, f. 1r (quinta mano), 12 de mayo de 1364. Los Jurados prestaron juramento de su cargo el día de Pentecostés en el palacio episcopal, donde entonces residía temporalmente el rey Pedro IV el Ceremonioso. La noticia sobre el estandarte izado en la única torre que quedó en pie puede leerse por ejemplo en H. SAMPER, Montesa Ilustrada, Valencia, 1669, vol. II, p. 479, n. 797.

24 S. CARRERES ZACARÉS, Ensayo de una bibliografía de libros de fiestas, Valencia, 1925, pp. 21 y ss.; citado por M. GÓMEZ-FERRER, op. cit. 2012, p. 42.

25 L. ALANYÀ. op. cit., 1515, privilegio real de Pedro II, fol. 139, col. 3.

26 AMV, Manual de Consells, A-15, f. 171, 21 de marzo de 1371, en S. CARRERES ZACARÉS, op. cit., 1925, I, pp. 29-30; la ayuda para las obras del palacio de la Reina en A-16, f. 93v, 24 de junio de 1372. 
a las sesiones. Este símbolo de autonomía ciudadana se trocó en instrumento para el castigo de los Unionistas cuando el rey hizo tragar a Joan Sala, cabecilla del movimiento, el bronce fundido de la campana ${ }^{27}$.

Recientemente Federico Iborra ha formulado la hipótesis de que las instituciones municipales se trasladaran en 1370 al palacio heredado por los descendientes de Teresa Gil de Vidaurre y Jaime I, sito al comienzo de la calle de las Cortes, frente a la catedral, lo que explicaría sus dimensiones, el tipo de fachada y el alcance de las reformas para adaptarlo a las nuevas funciones administrativas y representativas del municipio hasta 1376-137728. Si se admite esta hipótesis, resultaría que la cesión del edificio por parte de la corona tras extinguirse el linaje de Pedro de Jérica, habría puesto en manos del Consejo valenciano una construcción con una escala y distribución de ambientes propia de un palacio y una fachada monumental de doble torre que rivalizaba con la propia residencia del Real. El emplazamiento frente a la puerta de los Apóstoles de la catedral, al comienzo del eje viario de las calles de las Cortes y de Caballeros, y la vecindad de la corte del Gobernador se convertiría en el siglo XIV en un nodo fundamental de la red urbana.



Fig. 3. Casa de la Ciudad en el plano de Valencia de Tomás Vicente Tosca, 1704 (Valencia, Archivo Histórico Municipal).

La adquisición de este edificio puede encuadrarse en el renovado entendimiento entre la corona y el poder municipal después del conflicto de la Unión (1347-1348) y tras los dos asedios sufridos por Valencia en la guerra con Castilla, en los que la ciudad del Turia se mantuvo leal al monarca. También en la necesidad de dinero por

27 A. SERRA DESFILIS, op. cit., 2004, pp. 75-80.

28 F. IBORRA BERNAD, op. cit., 2012, I, pp. 191-213. La hipótesis tiene en cuenta lo sugerido por J.M. ZACARÉS, Memoria histórica y descriptiva de las Casas Consistoriales de la ciudad de Valencia, Barcelona, 1856. Si así fuera, la corte de la Gobernación se habría traslado al antiguo edificio de la Casa de la Cort, donde se habían instalado en 1311 los tribunales de la ciudad y se reunía en ocasiones el Consejo o asamblea municipal. 
parte del rey para reconstruir el Real mientras la ciudad pasaba a ocupar la residencia de Pedro de Jérica, gobernador en tiempos de la Unión y uno de los principales adversarios de la política ciudadana hasta su muerte ${ }^{29}$.

Así, en el último cuarto del siglo XIV la ciudad de Valencia vio tomar forma a las dos sedes principales del poder civil. De una parte, la reconstrucción del Real configuró el gran bloque rectangular con patio central del conocido como Real nuevo, con una de las pocas fachadas de piedra de la ciudad ante la explanada y el puente que cruzaba el cauce del Turia. El Llano del Real servía en ocasiones como espacio para justas, torneos y celebraciones en honor del poder del príncipe, como sucedió en 1336, cuando los caballeros valencianos rindieron homenaje a Pedro $\mathrm{IV}^{30} \mathrm{o}$ en la entrada real de Juan I en noviembre de 1392; o como lugar de reunión, según se determinó para las honras fúnebres de Pedro IV en $1387^{31}$. Su emplazamiento periférico, pero próximo al recinto amurallado, correspondía al modelo trazado por Francesc Eiximenis al describir su ciudad ideal, bella y bien edificada ${ }^{32}$; en Valencia, la ciudad con sus murallas, el puente del Temple, la Rambla de Predicadores en la actual plaza de Tetuán y el Real formaban un conjunto urbanístico bien definido. La altura de las torres y la reciedumbre de los muros asumían un valor simbólico para representar el poder real mientras quedaba asegurado el auxilio militar a la ciudad o desde ella al palacio a través del puente sobre el Turia. Al otro lado del río, tras las murallas, sin plaza que favoreciese su contemplación, pero anclada en el corazón de la vida urbana se alzaba la conocida ahora como Sala del Consell, con una fachada semejante a la de un palacio, necesitada de reformas inmediatas, que no tardaron en acometerse.

$\mathrm{Al}$ frente de las obras de ambos edificios estuvo el mismo maestro de obras, Bernat Boix. El 28 de julio de 1376 el monarca le confió opus regalis nostri regii civitatis predicte, ac ipsum regale cum ortis et aliis suis pertinenciis universis, con derecho a ser llamado maestro mayor de la obra, como habían hecho sus predecesores en el cargo y en especial el difunto maestro Vidal Auger, con el salario y los derechos que éste tenía. Los oficiales del rey y los herederos del maestro Auger debían reconocerle como maestro mayor del Real y entregarle las llaves del palacio ${ }^{33}$; en 1388 aún seguía como magister et custos hospicio regalis ${ }^{34}$. En enero de 1376 Bernat Boix había sido designado también maestro mayor de las obras municipales pocos meses y se le consideraba "muy apto y competente en aquel arte" ${ }^{35}$. Meses más tarde, el Consejo

29 M. RODRIGO LIZONDO, op. cit., 1975, pp. 161-166.

30 M. GÓMEZ-FERRER, op. cit., 2012, p. 34, sin indicar la fuente.

31 E. VIDAL BELTRÁN, Valencia en la época de Juan I, Valencia, 1974, pp. 98-99 y 118.

32 "En lo costat de la ciutat déu star lo palau del príncep ben fort e alt, qui haja exida defora lo mur: axí que tota vegada puxa metre dins la ciutat companya o lan puxa traer”, F. EIXIMENIS, Lo crestià (selecció), A. HAUF (ed.), Barcelona, 1994, pp. 188-189.

33 A. RUBIÓ I LLUCH, Documents per l'història de la cultura catalana mig-eval, Barcelona, 1921 , vol. II, p. 180, documento CXCIII.

34 H. BORJA, "Animals exòtics al Palau Reial de València", Boletín de la Sociedad Castellonense de Cultura, LXXVIII (2002), p. 76.

35 A. SERRA DESFILIS, "El mestre de les obres de la ciutat de València (1370-1480)", J.YARZA LUACES, F. FITÉ LLEVOT (eds.), L’artista-artesà medieval a la Corona d'Aragó, Lleida, 1999, pp. 399417, en particular, p. 403; y, op. cit., 2004, pp. 82-83, acerca de su papel como maestro de las obras muros y fosos de Valencia y de la Casa de la Ciudad. 
municipal adoptó un acuerdo que establecía un programa de obras con la doble finalidad de atender a las necesidades de espacio para la administración y de ensalzar la dignidad institucional de la sede del poder cívico: las salas de los tribunales, la cámara del Consejo secreto (el brazo ejecutivo del gobierno municipal), las prisiones y la gran sala para las reuniones de la asamblea del Consejo integrada por los representantes de las parroquias y los oficios. Cuando culminaron estas obras en abril de 1377, se colocó en el ángulo de la fachada una inscripción grabada sobre una antigua lápida romana que hoy se conserva en el Museo de Bellas Artes de Valencia ${ }^{36}$.

La competencia en la escena urbana del edificio renovado con el palacio del Real se manifestó al tener noticia el monarca de la intención de los Jurados de colocar una campana en el reloj público en la Casa de la Ciudad, pues Pedro IV entendía que "tales cosas no se deben tener sino en iglesias y palacios de reyes"; los Jurados valencianos respondieron que habían declinado el ofrecimiento del relojero alemán que había fabricado una pieza para la catedral, de dotar con otra la sede del poder municipal, pues consideraron este elemento como obra "supersticiosa y voluntaria" cuando había otros trabajos más urgentes, como puentes y caminos, dañados entonces por inundaciones ${ }^{37}$. El palacio del Real tardó todavía muchos años en disponer de un reloj, colocado en 1437 damunt lo terrat del reyal en el ala del edificio adyacente al jardín ${ }^{38}$ mientras que la ciudad optó primero por financiar en parte la obra y el mantenimiento de otro en la torre del campanario de la catedral, en virtud de un acuerdo con el cabildo suscrito en 1418, aunque acabó dotándose de otro, sin campana, en una de las torres de la fachada principal, la recayente a la calle del Reloj viejo ${ }^{39}$.

\section{Capillas}

De puertas adentro, ambos edificios concentraban el ornato en sus capillas y salas de representación. En el reinado de Jaime II el Real contaba con una sala para la reunión del Consejo real y una capilla, decorada con vidrieras desde $1317^{40}$. Estas vidrieras debían servir de modelo a la de la capilla funeraria de los Híjar en el convento de

36 Número de inventario 1.501. Véase F.M. GIMENO BLAY, "Materiales para el estudio de las escrituras de aparato bajomedievales. La colección epigráfica de Valencia”, Epigraphik 1988. Fachtatung für mittelalterliche und neuzeitliche Epigraphik, Wien, vol. 2, 1990, pp. 195-215, en particular p. 211 y facsímil 10.

37 A. RUBIO VELA, Epistolari de la València medieval (I), Valencia, 2003, pp. 73-74.

38 J. SANCHIS SIVERA, "Relojes públicos en Valencia durante los siglos XIV y XV", Almanaque Las Provincias, Valencia, 1914, pp. 223-231. Para decorar la casa del reloj y la campana que tocaba las horas, se compraron 2.000 rajoles blanques y un penell dorado con los escudos de Aragón y Sicilia

39 J. SANCHIS SIVERA, La catedral de Valencia, Valencia, 1909, pp. 111-114; M.M. CÁRCEL ORTÍ, "Vida y urbanismo en la Valencia del siglo XV. Regesta documental", Miscel-lània de textos medievals, 6 (1992), pp. 424, 428-429 y 471; A. SERRA DESFILIS, “Al servicio de la ciudad: Joan del Poyo y la práctica de la arquitectura en Valencia (1402-1439)”, Ars longa, 5 (1994) pp. 111-119, en especial, pp. 117-118; y op. cit., 2004, p. 95.

40 J.E. MARTÍNEZ FERRANDO, "Nuevos datos inéditos sobre el palacio del "Real" de Valencia", Boletín de la Sociedad Castellonense de Cultura, XXI (1945), pp. 165-174. 
santo Domingo de Zaragoza ${ }^{41}$. Se desconoce si esta capilla puede corresponder a la que persistió con este uso en la parte oriental del conjunto en el llamado Real viejo, reformada a principios del siglo $\mathrm{XV}^{42}$. La capilla se revistió de particular importancia como espacio de culto y celebración a tenor de lo dispuesto en las Ordinacions de cort de Pedro IV el Ceremonioso ${ }^{43}$. Como en las residencias reales de Mallorca, Perpiñán y Zaragoza, existían entonces en el Real de Valencia dos capillas con advocaciones diferentes, adscritas respectivamente a la casa del rey y a la de la reina. La capilla de santa Catalina se hallaba en la primera planta del patio de la reina. El inventario de los bienes de la reina María de Navarra, redactado en Valencia en 1348, meses después de su muerte en el Real, enumera entre las pertenencias de la difunta que se hallaron en sus apartamentos joyas de gran valor simbólico y material como coronas o diademas, tejidos lujosos y tres imágenes de oratorio, entre otros enseres; también se anotaron los ornaments de les capelles que formaban un ajuar litúrgico en el que sobresalían los libros ${ }^{44}$. La capilla de Nuestra Señora de los Ángeles se hallaba en el Real viejo, casi en el extremo opuesto del conjunto, aunque también se situaba en el lado norte del patio ${ }^{45}$.

En 1346 Pedro IV instituyó nuevas capellanías y beneficios en la capilla del Real de Valencia a fin de equipararla con las capillas reales de Zaragoza y Barcelona. Su esposa Leonor de Sicilia dispuso en su testamento que se instituyeran tres beneficios más en la capilla del Real de Valencia, con lo que hubiera superado la dotación de clérigos de las demás capillas palatinas de la Corona de Aragón entonces ${ }^{46}$. Como en otras residencias de la Corona de Aragón, el monarca quiso dotar esta capilla con un retablo que pintó Ramón Destorrents, encargado también de terminar el que había comenzado Ferrer Bassa para la capilla de Santa Ana del palacio de la Almudaina de Mallorca ${ }^{47}$. Otro pintor, Ferrer Querol, vecino de Valencia, fue nombrado en 1349 pictor maior operis nostri Regalis civitatis, oficio que acarreaba algunos privilegios,

41 F. MARTÍN DE BARCELONA, "La cultura catalana durant el regnat de Jaume II", Estudis franciscans, 92 (1991), p. 394; y F. ESPAÑOL BERTRAN, "El castillo real de Lleida en época medieval", Anuario de Estudios Medievales, 26 (1996), pp. 437-485, en especial p. 483.

42 A. ZARAGOZÁ CATALÁN y F. IBORRA BERNAD, "Una aproximación a arquitecturas desparecidas: el palacio Episcopal, el palacio de en Bou y la capilla del Real Viejo de Valencia”, Jaime I (1208-2008). Arquitectura año cero, Valencia, 2008, pp. 135-156, en especial, pp. 149-153.

43 F. ESPAÑOL BERTRAN, "Calendario litúrgico y usos áulicos en la Corona de Aragón bajomedieval: arquitectura y ornamenta”, Studium Medievale, 2 (2009), pp. 185-212.

44 F. IDOATE, "Inventario de los bienes de la Reina Doña María, esposa de Pedro IV, Rey de Aragón", Príncipe de Viana, VIII (1947), pp. 417-435.

45 M. GÓMEZ-FERRER, op. cit., 2012, pp. 76-77 y 132-134.

46 J. TEIXIDOR, op. cit., 1895, I, p. 87; G. ROHFLEISCH, "Der Ausbau der Pfalzkapelle zu Valencia durch Peter IV”, Homenaje a Johannes Vincke, vol. I, Madrid, 1962, pp. 185-192; y J. VINCKE, "El derecho de patronato de la Corona de Aragón en el Reino de Valencia”, Primer Congreso de Historia del País Valenciano, vol. II, Valencia, 1980, pp. 837-849.

47 F.P. VERRIÉ. "Una obra documentada de Ramón Destorrents", Anales y Boletín de los Museos de Arte de Barcelona, VI (1948), p. 340, documento III; y J.M. MADURELL MARIMÓN, "El pintor Lluís Borrassà: su vida, su tiempo, sus seguidores y sus obras", Anales y Boletín de los Museos de Arte de Barcelona, VIII (1950), p. 12, documento 4 . 




Fig. 4. Planta principal del palacio del Real según Manuel Cavallero, 1802 (París, Centre Historique des Archives Nationaux, Fonds Suchet).

y debía ser reconocido por el maestro mayor de las obras del Real ${ }^{48}$. Para las capillas del rey y de la reina, Pedro el Ceremonioso requería en 1362 los servicios de Guillem de la Via, magister de vedrieres con sus útiles y herramientas ${ }^{49}$ y en 1386 los del pintor Berenguer Figueres, quien policromó la techumbre de una de las capillas, probablemente la de Santa María de los Ángeles ${ }^{50}$. En 1376 Pedro IV había encargado a Pere Bernés una imagen de la Virgen de los Ángeles que el platero debía entregar ya terminada en 1378 como titular la capilla, aunque se obstinaba en retenerla para asegurarse el pago real de unas joyas ${ }^{51}$. Quizá esta imagen de la Virgen con el Niño se situaba en el centro del retablo de pintura de Ramón Destorrents o más bien en combinación con el retablo portátil de plata que acompañaba al monarca en sus traslados por las residencias reales de la Corona de Aragón ${ }^{52}$.

La función de servir de escenario a la piedad real y para la exhibición de reliquias distinguían estas capillas del oratorio que se instaló en la Casa de la Ciudad. El Consejo había acordado en 1392 decorar con pinturas murales "con epitafios e inscripciones del Crucificado y del Ángel protegiendo a la ciudad por disposición divina y otras figuras y pinturas que los Jurados estimen oportunas" alguno de los muros de la Sala

48 J. SANCHIS SIVERA, "Pintores medievales en Valencia", Archivo de Arte Valenciano (1928), pp. 1718; ahora con transcripción revisada en X. COMPANY, et alii, Documents de la pintura valenciana medieval i moderna I (1230-1400), València, 2005, p. 212, documento 200.

49 J.M. MADURELL MARIMÓN, "Documents culturals medievals (1307-1485)", Boletín de la Real Academia de Buenas Letras de Barcelona, XXXVIII (1979-1982), p. 311, documento 16.

50 M. GÓMEZ-FERRER, op. cit., 2012, p. 47; más noticias sobre el pintor, identificable con Bernat Figueres en X. COMPANY et alii, op. cit, 2005, pp. 344-345.

51 F. DURÁN CAÑAMERAS, "La escultura medieval en el Reino de Valencia (continuación)", Anales del Centro de Cultura Valenciana, 13 (1945), pp. 117-127; el equívoco con una pintura atribuida a un tal Pere Bernat ha sido aclarado por M. GÓMEZ-FERRER, op. cit., 2012, p. 43.

52 F. ESPAÑOL BERTRAN, op. cit., 2009, pp. 199-201. 
del Consell ${ }^{53}$. En 1395 se dispuso que ante el altar del Ángel Custodio de la ciudad se celebrase misa diaria en la cámara del Consejo secreto ${ }^{54}$. El conjunto de pinturas murales de ambas salas fueron obra del pintor nórdico Marçal de Sas, y mostraban en el frente principal de la Sala el Juicio Final, con el Paraíso y el Infierno, y en el muro de la Cámara del Consejo Secreto la Majestad divina y la imagen del Ángel protector de la ciudad, intercediendo por ella y otras figuras ${ }^{55}$. Las pinturas murales, en las que aplicaron plata y pan de oro además de los colores, debían de servir de fondo al retablo "dorado y bello" del altar de la Cámara del Consejo Secreto, por el que se pagaron 90 florines en $1397^{56}$. La imagen del Ángel Custodio constituía, por tanto, uno de los motivos principales y se relacionaba con la fiesta a él dedicada en Valencia y otras ciudades de la Corona de Aragón por aquellos años ${ }^{57}$. Años más tarde, en 1415, los Jurados se refirieron a la antigua costumbre de celebrar cada año con gran solemnidad la fiesta de san Miguel en honor del arcángel y de todos los santos del cielo, en especial del que guardaba la ciudad de Valencia ${ }^{58}$. En 1419 los regidores aludían a la capilla como quedam capella et altare erectum sub vocabulo sancti Michaelis constructa existant, y consta que en ella se veneraban las reliquias de la ciudad por el pago a Joan Llobet de la obra de talla con este destino por un importe de 15 libras en $1434^{59}$. Si bien no ha llegado hasta nuestros días el retablo dorado pagado en 1397, se tienen noticias indirectas de una intervención hacia 1470-1480 del platero Nadal Davó, que trabajaba por entonces en el retablo de plata de la catedral ${ }^{60}$. Este último dato apunta a una renovación de las imágenes y del ajuar de la capilla, en la que se incluirían sin duda el tríptico de Vrancke van der Stockt comprado en 1494, con la imagen del Juicio Final en la tabla central y de las obras de Misericordia en las alas

53 “Encara provehí e volgué lo present Consell que en la present Sala del Consell d'aquella sien fets de pinzell bellament pitafis o figures de crucifici e de l'àngel tenint en guarda la dita Ciutat per disposició divina e altres figures e pintures que seran mils vists als dits jurats o a la major part d'aquells", citado por M.A. ORELLANA, Valencia antigua y moderna, Valencia, 1923, III, p. 38. También en X. COMPANY et alii, op. cit., 2005, I, p. 358, documento 619.

54 Citado por E. VIDAL BELTRÁN, op. cit., 1974, pp. 105-106; ahora nuevamente transcrito por X. COMPANY et alii, op. cit., 2005, I, p. 387, documento 681.

55 J. RUIZ DE LIHORY, Diccionario biográfico de artistas valencianos, Valencia, 1897, p. 208 sitúa las pinturas en la cámara del Consejo secreto, opinión coincidente con la de L. TRAMOYERES BLASCO, "La capilla de los Jurados de Valencia”, Archivo de Arte Valenciano, V (1919), pp. 73-100, en especial, p. 76. El pago de 5.552 sueldos y 10 dineros por los gastos de decoración de la Sala Major y la Cambra de Consell Secret fue dado a conocer por J. SANCHIS SIVERA, "Pintores medievales en Valencia", Archivo de Arte Valenciano, XIV (1928), pp. 3-64, en concreto p. 49, y puede leerse en X. COMPANY, et alii, op. cit., 2005, I, p. 403, documento 715 .

56 X. COMPANY et alii, op. cit, 2005, I, p. 437, documento 801: "lo retaule daurat e bell segons a la cosa pertany fet per a l'altar de la Cambra de Consell Secret, on se diu tots jorns missa".

57 G. LLOMPART, "El Ángel Custodio en la Corona de Aragón en la Baja Edad Media (fiesta, teatro, iconografía", Fiestas y liturgia. Actas del coloquio celebrado en la Casa de Velázquez, Madrid, 1988, pp. 249-270.

58 Carta de los jurados de Valencia al mercedario fray Antoni Quexal publicada por A. RUBIO VELA (ed.), op. cit., 1998, II, p. 98.

59 La carta puede leerse en A. RUBIO VELA, op. cit., 1995, p. 18; otros datos en A. SERRA DESFILIS, op. cit., 2003, p. 94.

60 J. SANCHIS SIVERA, La catedral de Valencia, Valencia, 1909, p. 36. Ha establecido la relación entre la confusa alusión a Nadal Yrro en el folleto de J.M. ZACARÉS y VELÁZQUEZ, op. cit., 1856, p. 24 y el platero Nadal Davó F. IBORRA BERNAD, op. cit., 2012, I, pp. 305-307. 
(Museo Histórico Municipal de Valencia y Museo de Bellas Artes de Valencia, respectivamente), y acaso también la escultura de san Miguel arcángel que conserva el Museo Histórico Municipal ${ }^{61}$.

Esta puesta al día coincide significativamente con los encargos de retablos, uno pintado por Antoni Guerau y otro, dedicado a santa Catalina, que aportó Jacomart, aunque quizá no fuera de su mano ${ }^{62}$, y la adquisición de imágenes de bulto, importadas o pagadas a artífices forasteros, para las capillas del Real a lo largo del siglo XV: un Cristo crucificado traído desde Sicilia por Martín I y, sobre todo, el Cristo adquirido por Alfonso $\mathrm{V}$ al flamenco Martí Bossa por 300 florines de oro en 1425; otro oratorio grande, de madera, que costó 1100 sueldos pagados al mercader florentino Moreto de Doni en 1427, el encargo a los plateros italianos Guido d'Antonio y Giovanni da Pisa de una imagen de san Miguel venciendo al demonio por valor de 13.000 sueldos y la representación de piedra de la Pasión del escultor alemán Pere Staxar de 1449, si bien esta última pudo tener otro destino ${ }^{63}$. En la elección del arte foráneo, la preferencia por las imágenes de bulto y la renovación de los retablos cuesta descartar un afán de emulación de las autoridades municipales tras el esfuerzo llevado a cabo por la corona en las capillas del Real. Sin embargo, el solemne ceremonial cortesano, la exhibición de las reliquias reales y el traslado de la mayor parte de éstas desde el palacio real de Barcelona al Real valenciano en 1424 sancionaban la supremacía de la capilla como escaparate de la piedad del monarca, que suele evocarse a través de una miniatura del Salterio-libro de horas de Alfonso el Magnánimo de la British Library, iluminado en Valencia por Leonard Crespí ${ }^{64}$. En ella se ve una ceremonia en la capilla real, con el rey y otros miembros de su corte asistiendo al culto ante un retablo en forma de artesa. Antes de ser depositado como garantía de préstamo en la catedral de Valencia, el Santo Cáliz estuvo con otras piezas del tesoro religioso de los monarcas unos años en la capilla del Real ${ }^{65}$ y se ha señalado la coincidencia significativa en aquellos años de los primeros objetos decorados con la divisa artúrica del siti perillós

61 L. TRAMOYERES, "La Capilla de los Jurados de Valencia”, Archivo de Arte Valenciano, V (1919), pp. 73-100.

62 ARV, Mestre Racional, registro 9203, f. 22. Véase M. FRAMIS MONTOLIU y L. TOLOSA ROBLEDO, "Pintors medievals a la cort reial de València", XV Congreso de Historia de la Corona de Aragón (Jaca, 20-25 de septiembre de 1993), Zaragoza, 1996, I, vol. 5, p. 431; y M. GÓMEZ-FERRER, "Jacomart: revisión de un problema historiográfico", L. HERNÁNDEZ GUARDIOLA (coord.), De pintura valenciana (1400-1600). Estudios y documentación, Alicante, 2006, pp. 71-99, en especial, pp. 75 (Antoni Guerau) y 93-94 (Jacomart).

63 A. SERRA DESFILIS, op. cit., 2007, pp. 134-138, con la bibliografía allí citada; y J.V. GARCÍA MARSILLA, Art i societat a la València medieval, Catarroja, 2011, p. 252.

64 British Library (Londres), ms. Additional 28962, folio 281v. Véase A. VILLALBA DÁVALOS, La miniatura valenciana en los siglos XIV y XV, Valencia, 1964, p.129; J.V. GARCÍA MARSILLA, "El poder visible. Demanda y funciones del arte en la corte de Alfonso el Magnánimo”, Ars longa, 7-8 (1996-1997), pp. 33-47, en especial pp. 40-44; y F. ESPAÑOL BERTRAN, "El salterio y libro de horas de Alfonso el Magnánimo y el cardenal Joan de Casanova”, Locus amoenus, 6 (2002-2003), pp. 91-114, en particular, pp. 97,100 y $105-106$.

65 F. ESPAÑOL BERTRAN, op. cit., 2001, pp. 112-121; M. NAVARRO SORNI, "Pignora sanctorum. En torno a las reliquias, su culto y funciones del mismo", Reliquias y relicarios en la expansión mediterránea de la Corona de Aragón. El tesoro de la catedral de Valencia, Valencia, 1998, pp. 95-155; C. MARTÍN LLORIS, Las reliquias de la Capilla Real en la Corona de Aragón y el Santo Cáliz de la Catedral de Valencia, Tesis doctoral inédita, Universitat de València, 2004. 
o trono ardiente ${ }^{66}$. La entrega oficial a cuatro canónigos y tres jurados de las reliquias de san Luis de Toulouse, tomadas como botín en el ataque al puerto de Marsella en 1424, para que la ciudad las tuviera en custodia, si bien luego pasaron al tesoro catedralicio ${ }^{67}$, o la celebración del lavatorio de los pies en Jueves Santo (Mandatum) en la gran sala del Real por Alfonso V fueron otras ocasiones en que el monarca actuaba ante sus súbditos con un cierto sentido de la sacralidad en el palacio, incluso fuera del estricto ámbito de la capilla real ${ }^{68}$.

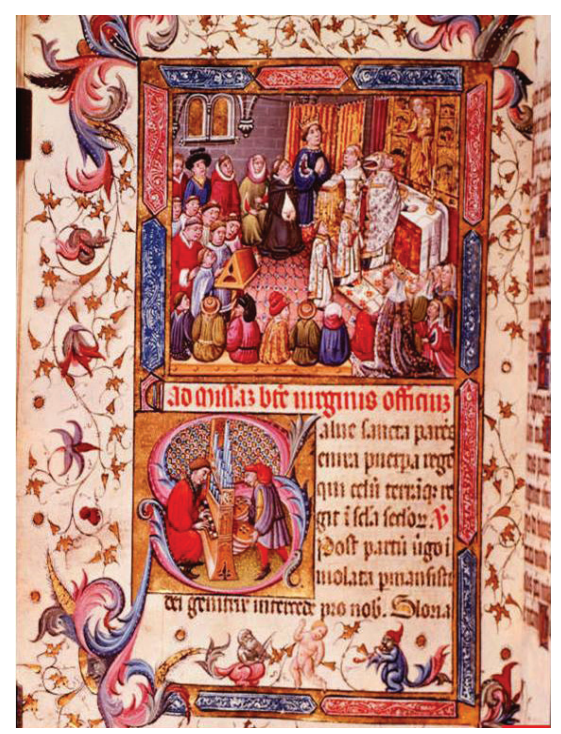

Fig. 5. Los reyes y su corte asisten al oficio en la capilla real. Miniatura de Leonard Crespí del Sallterio-libro de horas de Alfonso el Magnánimo (Londres, British Library, ms. Additional 28962, folio 281v).

\section{Salas de aparato: aver notables cases e notablement ordenades, axí en hedificis com en gran regiment, e en reebre persones notables altament}

Si en el ornato y dotación de las capillas el palacio del Real se anticipó y superó a la Casa de la Ciudad, no parece que los Jurados fueran en desventaja en sus iniciativas

\footnotetext{
66 J. MOLINA FIGUERAS, "Un trono in fiamme per il re. La metamorfosi cavalleresca di Alfonso il Magnanimo”, Rassegna storica salernitana, XXVIII/2, pp. 11-44, en particular, 2011, pp. 28-30.

67 Dietari del Capellà d'Anfos el Magnànim, J. SANCHIS SIVERA (ed.), Valencia, 1932, pp. 125-127; M. NAVARRO SORNI, op. cit., 1998, pp. 123-125; F. ESPAÑOL BERTRAN, "La Beata Stirps en la Corona de Aragón. Santa Isabel de Hungría y San Luis de Tolosa, culto e iconografía", Hagiografía peninsular en els segles medievals, Lleida, 2008, pp. 135-168, en especial, pp. 160-162.

68 A. RYDER, Alfonso el Magnánimo, rey de Aragón, Nápoles y Sicilia (1396-1458), Valencia, 1992, p. 383; y M. GÓMEZ-FERRER, op. cit., 2012, p. 122. Acerca del Mandatum practicado por los reyes de la Corona de Aragón en el marco de la liturgia del Jueves Santo, F. ESPAÑOL BERTRAN, op. cit., 2009, pp. 189-193.
} 
por embellecer las dos grandes salas de aparato de la sede municipal. La apariencia suntuosa de estos interiores dependía de las bóvedas y techumbres, de los pavimentos con azulejos de cerámica pintada, de las pinturas o colgaduras de los muros y del mobiliario de madera entallada, pero cobraba todo su significado en las ceremonias y recepciones. El estilo de vida cortesano del rey se desarrollaba en Valencia tanto dentro como fuera de la residencia real y comportaba actividades que sólo en parte albergaba el palacio, sede temporal de una corte ambulante. Es probable que las estancias de Juan I en la ciudad del Turia, de noviembre de 1392 a junio de 1393 y de septiembre del mismo año al verano de 1394, estimularan el afán de los regidores por atraer con más decisión a los reyes, lisonjeándoles con espléndidas recepciones y fiestas así como con una refinada producción artística enmarcada por la Casa de la Ciudad. Un papel semejante de catalizador de cambios en la actividad artística se ha atribuido a su sucesor, Martín I, y ha quedado bien documentado en el caso de Alfonso V el Magnánimo ${ }^{69}$. No sólo la historiografía ha constatado el aliciente de la presencia de la corte para la movilidad de los artífices y la producción orientada hacia las élites en lugares como los antiguos Países Bajos ${ }^{70}$ : también los contemporáneos se figuraban los encargos y gastos suntuarios que traía consigo la presencia del monarca, lo que servía de argumento a Pedro IV para convencer a los consejeros valencianos de que contribuyeran a las obras del Real ${ }^{71}$, o a Martín I para invocar los beneficios comerciales que en Barcelona tendría abrir una plaza frente al palacio real mayor en $1403^{72}$.

En 1392 Juan I ante el próximo viaje de su familia a Valencia, ordenó al mestre racional Pere d'Artés que realizara obras muy necesarias en el Real, pero le advirtió también de que apenas había fondos para sufragarlas, por lo que solicitaba ayuda económica a los jurados y prohombres de Castellón de la Plana y mandaba al maestre racional y a los bailes de Sagunto y Castellón que todas las rentas se invirtiesen en los trabajos del palacio ${ }^{73}$. El monarca mandó hacer acopio de madera para la techumbre de la cámara de los timbres del Real de Valencia, "pues queremos que se cubra de

69 M. MIQUEL JUAN, "Martín I y la aparición del gótico internacional en Valencia”, Anuario de Estudios Medievales, 33, 2 (2003), pp. 781-814; y J.V. GARCÍA MARSILLA, op. cit., 2011, pp. 239-311.

70 S. NASH, Northern Renaissance Art, Oxford, 2008, pp. 78-82, sobre el peso de la corte y las residencias reales en los antiguos Países Bajos.

71 En 1371 Pedro IV apelaba al Consejo municipal valenciano para que contribuyera a costear las obras argumentando que la nueva residencia animaría a los monarcas a pasar más tiempo en la ciudad y que con ellos llegarían gran número de cortesanos, oficiales, así como forasteros atraídos por celebraciones como el anunciado torneo entre un caballero inglés y otro francés. La asamblea municipal rechazó la petición instando al monarca a dirigirse a otras ciudades que habían ayudado a los castellanos a incendiar el palacio, pero meses después contribuyó a financiar las obras del palacio de la Reina en Barcelona. Véase S. CARRERES ZACARÉS, op. cit., 1925, I, pp. 29-30; M.M. CÁRCEL ORTÍ Y J. TRENCHS ODENA, op. cit., 1985, p. 1511.

72 "Item sen seguiran grans utilitats als singulars de la dita ciutat e assenyaladament als mercaders e menestral qui per la presència del dit senyor e de la senyora reyna e d'altres assenyalades persones dels quals l'estament reyal és acompanyat, poran vendre draps d'aur, de sede e de lana, pells, vexella d'argent, frens, selles e altres moltes coses necessàries al honrament d'aquelles", citado por N. DALMASES, "Arquitectura gòtica civil”, X. BARRAL I ALTET, (ed.), Art de Catalunya. Ars Cataloniae, 3: Urbanisme, arquitectura civil i industrial, Barcelona, 1998, pp. 117-169, con la cita en p. 123.

73 D. GIRONA LLAGOSTERA, "Itinerari del rei En Joan I", Estudis Universitaris Catalans, XIII (1931), pp. 144 y 146. 
madera"74. Se trabajó en el guardarropa del rey y en la cocina de la reina entre otras labores menores bajo la supervisión de Ramón Palau, sotsobrer del rey ${ }^{75}$. A su llegada el 24 de noviembre de 1392, tras el recorrido previsto en la entrada real, Juan I y Violante de Bar fueron agasajados al caer la tarde con un banquete servido en el Llano del Real, en una mesa de enebro rodeada de cortinas junto a un entarimado de considerable altura ${ }^{76}$. En 1393 las obras afectaban a una escalera en construcción y consta que en ellas participó el maestro Arnau Torres ${ }^{77}$. Seguramente la penuria de los cofres del rey explica la escasa ambición de las intervenciones documentadas en tiempos de Juan I el Cazador y de su hermano, Martín I el Humano, pero la intención de cubrir con madera, quizá pintada y tallada, una de las salas principales del Real, manifiesta un prometedor interés por esta solución, que mantendría, si no lo acrecentó, su sucesor a su paso por Xàtiva o Barcelona. En 1403 el baile general del reino de Valencia, Nicolau Pujades, pedía ayuda al Consejo municipal para costear la madera necesaria "a fin de obrar en su Real", contribución que fue denegada ${ }^{78}$. En las descripciones literarias coetáneas de palacios imaginarios las techumbres en oro y azur, de ingeniosa traza, son un tópico muy difundido y un autor coetáneo como Francesc Eiximenis compara el alto precio de una techumbre entallada por manos maestras en buena madera con la relativa economía de las bóvedas. La labor escultórica combinada con otros efectos en relieve de molduras, resaltes o los mocárabes de abolengo islámico se habían convertido para entonces en una forma de ornamentación lujosa que distinguía los palacios de otros ambientes cubiertos con alfarjes más sencillos. Si era menester, el efecto de ostentación podía renovarse con poco gasto, al compás de las modas, los cambios de propiedad y las reformas interiores. La heráldica, las divisas o inscripciones conferían un aspecto singular a las techumbres, de manera que en ellas se celebraban el propio linaje, un ideal caballeresco o el orgullo institucional ${ }^{79}$.

Desde finales del siglo XIV, en los recién acondicionados palacios de gobierno cívico las techumbres no tardaron en convertirse en elementos distinguidos por su decoración, por voluntad las oligarquías urbanas de la Corona de Aragón dentro de un

\footnotetext{
74 "Car de fusta volem que sia cuberta", J. M. ROCA, "Johan d'Aragó", Memorias de la Academia de Buenas Letras de Barcelona, XI (1929), p. 216, citado por J. RUBIÓ I BALAGUER, op.cit., 1985, p. 129.

75 Archivo del Reino de Valencia (en lo sucesivo ARV), Mestre Racional, registro 9157. Más detalles sobre estas obras en M. GÓMEZ-FERRER, op. cit., 2012, pp. 48-50.

76 E. VIDAL BELTRÁN, op. cit., 1974, pp. 98-99.

77 Archivo de la Corona de Aragón, Reial Patrimoni, Mestre Racional, registro 393, f. 139 se pagan 500 florines a Francesc Alguecer, guardia del Real de Valencia para que los invierta en obra de una escalera que "el dit senyor rey fa fer en lo dit Reyal" en mayo de 1393, noticia facilitada por la Dra. Matilde Miquel; ARV, Bailía General, pergamino $n^{\circ} 221$, carta de pago de 184 sueldos y 10 dineros a Arnau Torres, maestro de obras, por la mano de obra y el material empleados en las obras del Real (30 de diciembre de 1393).

78 AMV, Manual de Consells, A- 22, f. 270r.

79 Acerca del aprecio por las techumbres talladas y polícromas véase A. SERRA DESFILIS y O. CALVÉ MASCARELL, "Iconografía cívica y retórica en la techumbre de la Sala Dorada de la Casa de la Ciudad de Valencia", en L. BUTTÀ (ed.), Narrazione, exempla, retorica. Studi sull'iconografia dei soffitti dipinti nel Medioevo mediterraneo, Palermo, 2013, pp. 179-231, en especial, pp. 180-184; para las fuentes véase J. DOMENGE y J. VIDAL, "Documents relatifs à la décoration pictural des plafonds dans la Couronne d'Aragon (1313-1515)", Aux sources des plafonds peints médiévaux. Provence, Languedoc, Catalogne, Capestang, 2011, pp. 179-217.
} 


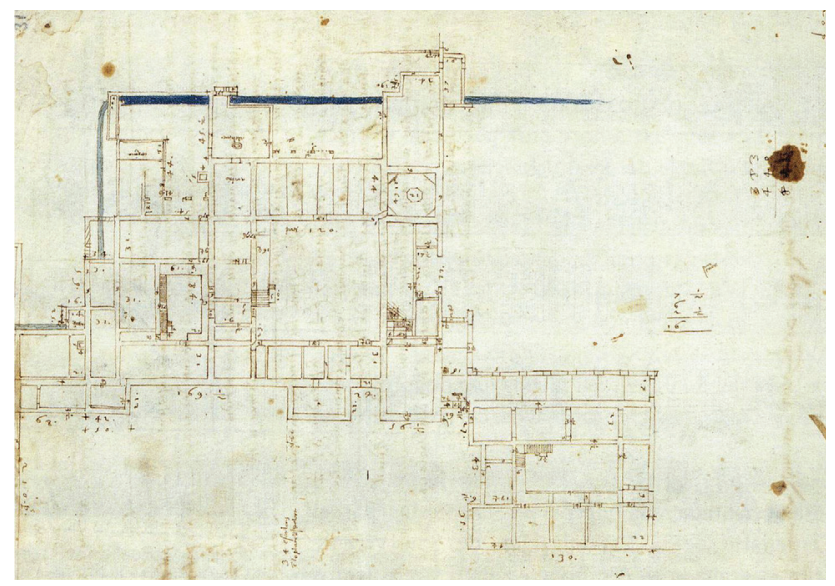

Fig. 6. Plano del palacio del Real, siglo XVI (Madrid, Biblioteca Nacional de España, Varios de topografía española ms. 18225, f. 313r).

propósito general y declarado de embellecimiento de estos edificios ${ }^{80}$. En la Casa de la Ciudad de Valencia el consejo municipal compró paños para engalanar los asientos y el pavimento de su salón de sesiones en 1391 y en agosto del año siguiente se acordó decorar la Sala del Consell con las pinturas de Marçal de Sas ya descritas, coincidiendo con una estancia del rey Juan I. En las visitas reales esta sala era el lugar de recepción de los monarcas, como demuestran los gastos en su decoración y en los sitiales que para el rey Martín I y su esposa se pagaron a Joan del Poyo en 1405. Labores de carpintería y cierre de los vanos de las salas principales se recogen también en la documentación de estos años, manifestando el esmero puesto en el acondicionamiento de las nuevas estancias. Las techumbres de estos espacios eran algo más que la cubierta visible y se cuidaba su apariencia respecto al valor de los objetos que custodiaban y de las funciones que cumplían. Así para el archivo de la Escribanía, continente de los manuscritos más valiosos de la ciudad, mandó hacerse en 1412 "una techumbre gentilmente obrada, del tamaño y forma que sean necesario" $"$. Con tales iniciativas, el municipio valenciano quiso hacer valer sus fueros y privilegios frente a la nueva dinastía Trastámara, recién entronizada, al tiempo que procuraba descollar entre el resto de ciudades de la Corona de Aragón sirviéndose también de la pompa y riqueza de la Casa de la Ciudad.

Mientras Valencia atraía a Alfonso el Magnánimo y financiaba en parte su política de expansión mediterránea, los ediles quisieron revestir de un esplendor singular las salas más representativas del palacio público como manifestación de la prosperidad

80 A. SERRA DESFILIS y O. CALVÉ MASCARELL, op. cit., 2013, pp. 183-184.

81 "Un sostre gentilment obrat, de aquella grandea e manera qu·y sia obs e lo fet requerrà". Véase A. SERRA DESFILIS, op. cit., 2004, pp. 74-87. La última noticia fue citada por S. CARRERES ZACARÉS, Libre de Memòries de diversos sucesos e fets memorables e de coses senyalades de la ciutat e regne de València (1308-1644), Valencia ,1930-1935, I, pp. XI-XII. 
y el buen gobierno que atribuían a su política. En 1418 los regidores decidieron habilitar una nueva sala en la Casa de la Ciudad y encomendaron los trabajos a Joan del Poyo para que se obrase "de talla, oro y pinturas" y la obra resultase "bella y costosa" 82 .

La riqueza y el brillo de la decoración justificaron que la sala nueva se denominara cambra daurada y sirviera para acoger las reuniones de los jurados y otras funciones de aparato. Bajo la techumbre tallada con figuras de profetas en los canes y abigarrados motivos fantásticos, lúdicos y la arrogante repetición del escudo de la ciudad se colocó un pavimento de azulejos de Manises con el escudo real e inscripciones (1421), que ofrecía el contrapunto en azul cobalto y blanco al resplandor colorido de la techumbre. Aquel año las autoridades municipales aprobaron que se postergasen todas las obras de la ciudad salvo la sala dorada, con el fin de acelerar su conclusión. ${ }^{83}$

El 15 de abril de 1428 el rey Alfonso el Magnánimo fue recibido solemnemente en la nueva sala de la Casa de la Ciudad de Valencia tras haber mostrado su interés por conocer la techumbre de este ambiente. Aunque la obra no estaba del todo policromada, había que aprovechar la estancia del rey en la ciudad, que no se prolongaría mucho tiempo, para halagarle y mostrar la magnificencia del municipio valenciano. La marcha de Alfonso $\mathrm{V}$ pudo influir en la lenta culminación de las labores pictóricas que no terminarían hasta 1458, el mismo año de su muerte en Nápoles.

En 1441 el jurado Guillem Solanes instó a que la empresa se concluyera, pues de la notable e bella cambra, la qual costava ço que fet hi era molta quantitat, empero que no era acabada sólo faltaba pintar y dorar las jácenas, que ya estaban colocadas. ${ }^{84}$ Queriendo evitar que los trabajos resultaran gravosos en exceso y ajenos a toda urgencia, los consejeros acordaron decorar dues bigades cada año, de modo que entre 1442 y 1445 , se culminó la obra. En los años transcurridos desde el comienzo de la armadura se habían producido desperfectos que hubo que reparar con trabajos de albañilería en las paredes y ventanas de la cambra daurada y la sustitución de una de las jácenas, pues estaba podrida. Todavía en 1447-1448 el maestro de obras Francesc Baldomar eligió las losas de mármol de Portaceli para el suelo de la sala, con la ayuda del carpintero Salvador Vinyals. A principios de 1448 también se ordenó abrir dos ventanas, una frente a la entrada y la otra en el muro que daba a la calle, con sus vidrieras, rejas y cuanto fuese necesario. ${ }^{85}$ Más tardías e incisivas en la imagen de este interior fueron las labores de carpintería en madera de roble de Flandes con un acabado polícromo y dorado que estaban en curso entre 1448 y 1449. Aunque la documentación no lo especifica, es probable que se trabajase entonces en el mobi-

\footnotetext{
82 Los decisiones se adoptaron el 14 de mayo y del 5 de noviembre manifestando que la obra debía continuarse y acabarse "axí bella e costosa com fer se puxa,[...] en manera que en tota part se puxa comendar e fer honorable raonament per les gents, car cové a axí egrègia e notable ciutat com aquesta aver una insigne casa e costosa". Véase J. TEIXIDOR, op. cit., 1895, vol. I, p. 166; L. TRAMOYERES BLASCO, "Los artesonados de la antigua Casa Municipal de Valencia", Archivo de Arte Valenciano, III (1917), pp. 31-71, en particular, pp. 48-50.

83 AMV, Manual de Consells, A-27, f. 320v, 27 de julio de 1421.

84 Citado por L. TRAMOYERES BLASCO, op. cit., 1917, p. 55.

85 AMV, Manual de Consells, A-34, f. 51v, 23 de enero de 1448. No consta si este solado de piedra implicó la sustitución total y parcial del pavimento cerámico con el escudo de la ciudad encargado en 1421.
} 
liario de la sala dorada, consistente en una tarima, un dosel y los sitiales que debían ocupar los jurados, pues en 1451 los carpinteros Jaume y Francesc Pons cobraron sus jornales por la obra del dosser de la dita cambra, decorada con molduras, coronas y fulles o roses de fusta de roure por Ferrando Goçalbo al año siguiente. ${ }^{86}$ Todavía en 1458 se labraron dos portales, cuyo emplazamiento no especifica la documentación. ${ }^{87}$

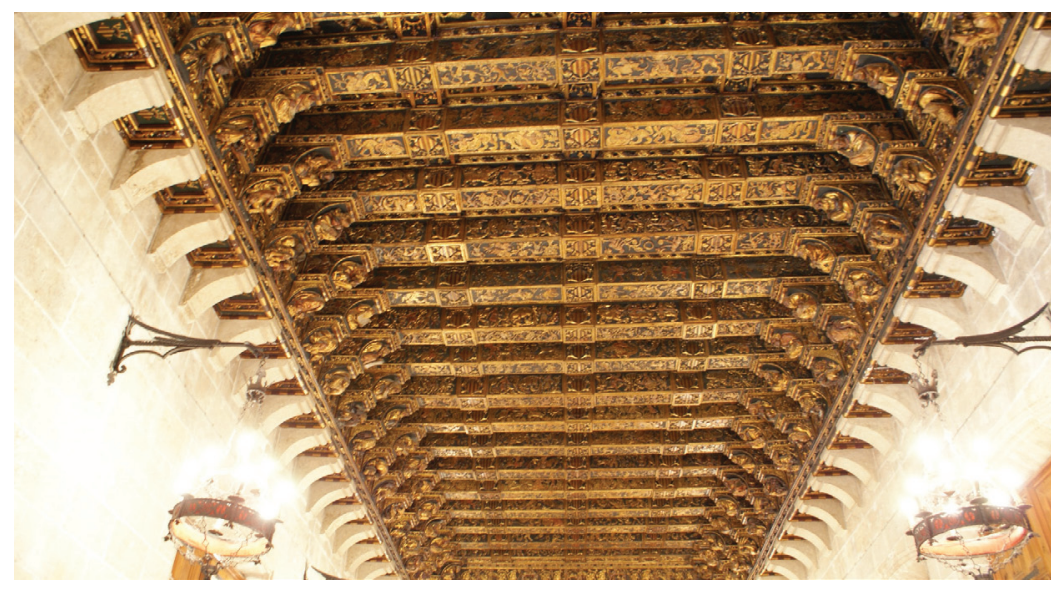

Fig. 7. Alfarje procedente de la sala dorada de la Casa de la Ciudad de Valencia, ahora en el salón del Consulado del Mar de la Lonja de mercaderes (fotografía: Óscar Calvé).

Uno de los motivos que justifican la interrupción de las obras de la Cambra Daurada fue la reconstrucción de la Sala del Consell, para reparar los daños ocasionados por el incendio que a principios de 1423 había arruinado la cubierta ${ }^{88}$. La renovación se decidió en el Consejo del 15 de octubre pero la dificultad de abastecerse de madera y la falta de capital para emprender la obra aconsejaron en un primer momento encargar a una comisión de expertos mestres d'obra de vila, fusters, piquers e altres el examen del proyecto para que a consell de les quals se faça la dita obra ${ }^{89}$. El consejero Gabriel de Palomar apeló en su denuncia al prurito de prestigio -la gran vergonya e càrrech- en la asamblea del 3 de noviembre, hasta convencer a sus miembros para que reparase la obra de manera sencilla ${ }^{90}$. Sólo una vez acabadas las reformas del edificio comienza el emplazamiento de la cuberta sobirana, el alfarje de la Sala dels Àngels, así llamada por la decoración de angelotes que sostenían los escudos de la ciudad. El 20 de febrero de 1427 se firmaban las capitulaciones que detallan el

86 L. TRAMOYERES BLASCO, op. cit., 1917, pp. 31-71 analizó las fuentes sobre el proceso constructivo y decorativo de la techumbre, que puede completarse con lo aportado por A. SERRA DESFILIS, op. cit., 2004, pp. 87-90.

87 AMV, Manual de Consells, A-36, f. 106 v y 112, 4 y 25 de agosto de 1458.

88 A. SERRA DESFILIS, op. cit., 2004, p. 90.

89 L. TRAMOYERES BLASCO, op. cit., 1917, p. 39.

90 Açò añadit que la dita obra sia plana, L. TRAMOYERES BLASCO, op. cit., 1917, p. 39. 
proyecto ${ }^{91}$. Éste consistía en una techumbre plana originada por el tendido horizontal de vigas embebidas en las paredes de la sala. Una gruesa cornisa de madera recorría el perímetro de la estancia, en la que descansaban los canes esculpidos que recogían el peso de las jácenas. El documento recapitula con detalle cada uno de los elementos del alfarje, cuyo coste se estipuló en 500 florines de oro, incluyendo los salarios y la compra de la madera necesaria que Joan del Poyo, en calidad de maestro principal de las obras, era responsable de suministrar ${ }^{92}$.

La proporción modulada de la serie de frisos se corresponde con el programa iconográfico, creando un equilibrio figurativo bien traducido sobre el plano geométrico. Como en la Cambra Daurada, una de las ventajas de la combinación de vigas, molduras y ménsulas era la posibilidad de disponer de múltiples espacios para desarrollar un amplio programa decorativo que enriqueciese la cubierta. La obra de talla se contrató con los maestros Andreu Çanou y Joan Lobet, ymaginaires, que se encargarían de la decoración escultórica de los treinta y dos canes, los mayores con figuras de ángeles con lo senyal de la dita ciutat posat en forma de tarja; los menores con figuras de profetas, según los quatre que han ja obrats e mostrats als dits honorables jurats per mostra ${ }^{93}$.

De este modo concluía una larga etapa de trabajos que configuran un espacio destacado por la riqueza de su ornato figurativo y dorado, así como por el aparato con que revestían sus sesiones los jurados valencianos. En aquel tiempo Alfonso V había recibido cuatro veces una subvención anual de 1000 florines para que prolongase su estancia en Valencia, antes de partir definitivamente en 1432 hacia Italia, de donde ya no regresaría. ${ }^{94}$ Se había conseguido con no poco gasto renovar la imagen de las dos grandes salas de la Casa de la Ciudad, llamando la atención del monarca con el esplendor de las techumbres y los programas iconográficos de su figuración.

El rey no podía permanecer ajeno a esta iniciativa, embarcado como estaba en un amplio proceso de renovación del palacio del Real en aquellos mismos años ${ }^{95}$. Nuevos ambientes de representación fueron habilitados para el programa político de exaltación del poder real en y desde la ciudad de Valencia concebido por Alfonso el Magnánimo antes de la conquista definitiva de Nápoles en 1442. El esfuerzo más cuantioso y significativo para la historia del palacio se dedicó a las salas de aparato y a renovar su imagen arquitectónica a partir de 1420, cuando fue nombrado Bernat Mercader guàrdia del Real con el encargo expreso de procurar reformas y mejoras

91 AMV, Protocolos: Notario Antoni Pascual, años 1425-1427. Aludido por L. TRAMOYERES BLASCO, op. cit., 1917, pp. 45-46.

92 AMV. Varias. Sisas, signatura $\mathrm{v}^{2}-5$, ff. $87 \mathrm{v}-88 \mathrm{r}$.

93 AMV, Notales: Notario Antoni Pascual, años 1427-1450. Citado por L. TRAMOYERES BLASCO, op. cit., 1917, pp. 47.

94 F. SEVILLANO COLOM, Préstamos de la ciudad de Valencia a los reyes Alfonso Vy Juan II (14261472), Valencia 1966; A. RYDER, op. cit., 1992, pp. 151-220 para este período de la vida del monarca; apunta las consecuencias artísticas J.V. GARCÍA MARSILLA, "La estética del poder. Arte y gastos suntuarios en la corte de Alfonso el Magnánimo (Valencia, 1425-1428)", XVI Congresso Internazionale di Storia della Corona d'Aragona. Celebrazioni alfonsine (Napoli, 1997), Napoli, 2000, II, pp. 1705-1718.

95 A. SERRA DESFILIS, op. cit, 2007, pp. 134-142; M. GÓMEZ-FERRER, op. cit., 2012, pp. 59-92 revisan las transformaciones del palacio en este reinado. 
tanto en el palacio como en los jardines ${ }^{96}$. En 1437 Alfonso el Magnánimo designó custodio y suboperarius fabrice Palacii a Joan de Bonastre, cargos en los que fue confirmado por Juan II en $1458^{97}$. Debe tenerse en cuenta que el Real albergaba, además de los apartamentos del rey y la reina, la sala de la Audiencia, desde tiempos de Pedro IV, y ambientes tan cualificados como la Cambra dels Àngels, una pieza de considerable tamaño, con bóveda de crucería de cinco claves sobre planta cuadrangular, que funcionaba como una rótula entre los patios del Real vell y del Nou, con una presencia prominente en la fachada principal del edificio en forma de torre. Al oeste, en el Real nou, junto a la capilla de santa Catalina, sobresalía una gran sala rectangular de aparato en el piso alto, que debía revestirse con tapices y colgaduras y cabe identificar con la Cambra de paraments, semejante a las de otras residencias de los monarcas de la Corona de Aragón. Notables obras de reforma se acometieron, a partir de 1420, en el Real vell, situado a levante, donde estaban la capilla inferior de santa María de los Ángeles, los apartamentos del rey y una gran sala entre las torres de la fachada principa ${ }^{98}$. En 1423 el carpintero Guillem Just había construido a destajo un corredor cubierto con techumbre de madera que comunicaba la Cámara de los Ángeles con la torre vecina del Real viejo, donde se situaron los apartamentos del Rey en tiempos de Alfonso $\mathrm{V}^{99}$. La Cámara del Rey con su lit de paraments estaba en la torre noroeste del Real vell, con vistas a los jardines, próxima a la Cambra dels Àngels y comunicada con ésta a través de una galería que cabalgaba sobre el arco de paso a los jardines, pero el monarca disponía también de un guardarropa con un tinell para exhibir la vajilla de lujo, un lit de repós y una recámara o estudi, que debía de ser un espacio más reducido y reservado ${ }^{100}$. Para la sala principal del Real nuevo se compraron columnas prefabricadas en Gerona desde 1421 hasta 1423, destinadas en su mayor parte a las ventanas, pero al menos cuatro de ellas sirvieron para decorar los muros ${ }^{101}$. Un portal de piedra daba entrada al salón desde la torre más próxima a las

96 Bernat Mercader era sobrino de Berenguer Mercader, uno de los hombres de confianza del rey y alcanzaría los títulos de cambrer y baile general del Reino de Valencia y desempeñaría importantes misiones diplomáticas al servicio de la corona. M. TINTÓ SALA, Cartas del baile general de Valencia Joan Mercader al rey Fernando de Antequera, Valencia, 1979, pp. 21-31.

97 El cargo incluía también el cuidado de los animales y del jardín. Juan II accedió en 1459 a la petición de que el oficio pasara a titularse alcaide en vez de custodio. L. FULLANA, op. cit., 1929, pp. 117-119.

98 M. GÓMEZ-FERRER LOZANO, "La reforma del Real vell de Valencia en época de Alfonso el Magnánimo. Recuerdo del palacio desde Sicilia”, Lexicon, 8 (2009), pp. 7-22, revisa esta fase del proceso constructivo.

99 ARV, Mestre Racional, registro 11605, f. 1r: cobrir la naya e torra qui proceeix de la cambra dels àngels a una torra del Reyal vell. De estos trabajos se encarga Guillem Just, mestre fuster y manobre. Aportó la madera el carpintero Jaume Stopinyà a obs de cobrir la cambra de la torre del Real vell qui és damunt la capella del dit Real e la naya e pasadís que havets feta fer en dita torre e la cambra dels Angels del Real del senyor Rey e per cobrir encara la casa que havets feta fer nova en la partida del dita Real vell. ARV, Bailía General, $\mathrm{n}^{\circ}$ 44, f. 345v, 4 de diciembre de 1423.

100 ARV, Mestre Racional, registro 11605, f. 79v.

101 J. GUIRAL HADZIIOSSIF, Valencia, puerto mediterráneo en el siglo XV (1410-1525), Valencia, 1989, p. 413; F. ESPAÑOL BERTRAN, "Los materiales prefabricados gerundenses de aplicación arquitectónica (siglos XIII-XV)”, J. YARZA y F. FITÉ (eds.), op. cit., 1999, pp. 94 y 102; y “Las manufacturas arquitectónicas en piedra de Girona durante la Baja Edad Media y su comercialización", Anuario de Estudios Medievales, $39 / 2$ (2009), pp. 963-1001, en especial, p. 54. 
caballerizas, en la parte posterior del Real ${ }^{102}$. Este salón estaba preparado para que sus muros se recubrieran con colgaduras como tapices, guadamecíes, tejidos pintados o brocados, y disponía de bancos de madera y un tinell que la caracterizaban como un espacio principal dentro del palacio ${ }^{103}$. Junto a él estaba una sala más pequeña on se té consell secret, o sea donde se reunía el monarca con el Consejo real y una sala llamada de los ujieres ${ }^{104}$. Los ujieres de armas estaban encargados de la custodia del rey y debían permanecer en la antesala de la cámara real, según las Ordinacions de cort de Pedro el Ceremonioso ${ }^{105}$. A partir de 1432, a estos ambientes de representación se sumó entre las torres de la fachada del Real vell una gran sala rectangular, con elaborada techumbre de madera y cuatro amplios vanos rectangulares divididos por columnillas con arquillos trilobulados, como las que todavía pueden apreciarse en la fachada principal en diversas vistas y los planos históricos ${ }^{106}$.

El rey procuró adquirir lujosos tejidos y colgaduras apropiadas para revestir los muros de estas salas de aparato, como era costumbre en la época: en 1424 Alfonso el Magnánimo compró una pieza de raso y tres tapetes al mercader Domingo Jaume por 40 florines de oro para decorar aule nostre Regalis Consilii, es decir, la sala del Consejo Real, y diez años después se refería en un documento a los tapices flamencos que pensaba encargar al maestro Guillem del Vexell, que cabe identificar con Guillaume au Vaissel de Arras, per a parament del nostre Reyal de València, axí per la gran sala del Tinell com per la cambra dels Àngells e algunes altres ${ }^{107}$. Los tapices no parecen haber estado al alcance del erario municipal, por lo que distinguían las salas de repre-

102 ARV, Mestre Racional, registro 9137, años 1453-1454: el portal de piedra fue labrado por Francesc Baldomar y otros canteros y en él se puso una puerta de madera de roure de Flandes tallada por Bernat Ruvio y otros carpinteros.

103 ARV, Mestre Racional, registro 11605, f. 31: en noviembre de 1423 se pusieron barres a la gran sala per empaliar aquella; la operación se repite en 1428 per lo convit que l'infant don Pedro, jermà del senyor Rey feu en la dita sala del Real, Mestre Racional. Registro 9134, 25 de enero de 1428.

104 ARV, Mestre Racional, registro 11605: la casa on se té consell secret, que hix a la gran sala (f. 80v-81r); la cambra del senyor Rey aprés la cambra dels àngels y una cambra qui hix a la sala gran appellada d'uxers. (f. 88r-v). Para la sala del Consejo hizo ocho bancos en 1435 el carpintero Jaume Estopinyà, véase J. SANCHIS SIVERA, "La escultura valenciana en la Edad Media", Archivo de Arte Valenciano, X (1924), pp. 3-29, p. 11.

105 Todavía a finales del siglo XVIII se podía leer una lápida en mármol negro con la inscripción cambra de uxer del senyor Rey "sobre la entrada a la galería principal del palacio", que en 1795 estaba decorada con los retratos de virreyes y capitanes generales que gobernaron el reino y debió de servir en su tiempo como antesala de los aposentos reales. Véase M. ORTIZ ZARAGOZÁ, "Lápida del Palacio del Real", Diario de Valencia, 8 de septiembre 1795.

106 ARV, Mestre Racional, registro 11606, f. 2r: certes obres en lo Reyal vell...ço ès en cobrir axi de fusta qu'és entre les.II. torres del dit Reyal vell que respón envers la rambla com encara en acabar de pedra les finestres que són començades de fer en la dita sala e en altres obres necessàries per acabar la dita sala (1442). En estos trabajos participaron, entre otros, los carpinteros Antoni Adzebro y los maestros de obras Francesc Baldomar en la cantería y Jaume Gallén en la albañilería. Las obras de esta sala se acabaron entre 1445 y 1446, Mestre Racional, registro 11607, f. 1-93r; J. SANCHIS SIVERA, "Maestros de obras y lapicidas valencianos en la Edad Media", Archivo de Arte Valenciano, XI (1925), pp. 423-52, especialmente, pp. 43-44; M. GÓMEZ-FERRER, op. cit., 2012, pp. 80-86.

107 J.M. MADURELL MARIMÓN, op. cit., 1979-1982, p. 396 (documento 118) y p. 397 (documento 119). Sobre la identidad de este maestro y marchante de tapices y el contexto de estos encargos para el Real de Valencia véase R. CORNUDELLA, "Alfonso el Magnánimo y Jan van Eyck. Pintura y tapices flamencos en la corte del Rey de Aragón”, Locus amoenus, 10 (2009-2010), pp. 39-62, en especial, pp. 45-47. 
sentación del Real, acaso con más vigor que la propia arquitectura. Los pavimentos estaban formados por azulejos fabricados en Manises y ostentaban las divisas, lemas y empresas del Magnánimo, como el trono ardiente o siti perillós, el libro abierto o el mijo, como parte de un programa político y ornamental cuidadosamente calibrado ${ }^{108}$. La escultura decorativa, sobre todo en madera, debía de tener un papel notorio en la decoración del interior con elementos tan curiosos como los tres ángeles de madera con armas y elementos heráldicos de la dinastía, quizá destinados a la Cambra dels Àngels, los doce capiteles de la gran sala, tallados en madera ab cares de baboyns, para colgar los tapices o los tres bestions y la carpintería policromada de la puerta de la primera cambra de la quarta torra del dit Reyal vell tallados por Martí Llobet en $1432^{109}$, pero no se desprende de la documentación que hubiera nada comparable a la deslumbrante sala dorada de la Casa de la Ciudad que el monarca quiso visitar en 1428 .

Si cabe suponer que tales ambientes fueran accesibles para unos pocos, las cuatro torres puestas en los ángulos del patio del antiguo alcázar dominaron en lo sucesivo la silueta de la fachada: la primera, donde se albergarían las habitaciones del rey, se comenzó en 1420, se cubrió con bóvedas tabicadas en distintos niveles comunicados por una escalera de piedra y quedó coronada con almenas y un campanario en $1424^{110}$; a ésta, vecina a los jardines, siguió pronto la torre sureste en 1427 hasta que en los años cincuenta todo el conjunto había sido notablemente transformado ${ }^{111}$. De la importancia conferida a estas cuatro torres almenadas y la que se levantó sobre la Cambra dels Àngels da una idea que en 1434 fuera enviado Joan Bonet a Sicilia, donde se encontraba el rey para presentarle los modelos o mostres de les quatre torres fetes e obrades en fusta ${ }^{112}$ y en 1441 se hizo lo propio con la torre que debía levantarse sobre la Cambra dels Angels ${ }^{113}$. En 1398, fray Anselm Turmeda imaginó en sus Cobles de la divisió del Regne de Mallorques un palau molt alt murat, de torres environat, porque los palacios tendían a conservar algo del aspecto militar de los castillos, en particular los torreones por más que su eficacia defensiva fuera discutible $^{114}$. Las torres seguramente eran ya uno de los rasgos más definidos del edificio

108 V.M. ALGARRA PARDO, "Espacios de poder. Pavimentos cerámicos y escritura en el Real de Valencia en época de Alfonso el Magnánimo", XV Congreso de Historia de la Corona de Aragón, tomo I, vol. 3, Zaragoza, 1996, pp. 271-289. A propósito de estas divisas véase R. BELTRÁN LLAVADOR, "Invenciones poéticas en Tirant lo Blanc y escritura emblemática en la cerámica de Alfonso el Magnánimo", De la literatura caballeresca al Quijote, Zaragoza, 2007, pp. 59-64; y, sobre todo, J. DOMENGE I MESQUIDA, "La gran Sala de Castelnuovo. Memoria del Alphonsi regis triumphus", G.T. COLASANTI (ed.), Le usate leggiadrie.I cortei, le cerimonie, le feste e il costume nel Mediterraneo tra il XV e il XVI secolo, Montella, 2010, pp. 290338, en especial, pp. 307-325; y J. MOLINA FIGUERAS, op. cit., 2011, pp. 11-44.

109 ARV, Mestre Racional, registro 11607, f. 38r; J. SANCHIS SIVERA, op. cit., 1924, pp. 19-20. El portal y las ventanas de la misma torre habían sido esculpidos en piedra años antes por Joan Llobet.

110 ARV, Mestre Racional, registro 11605.

111 M. GÓMEZ-FERRER, op. cit., 2012, pp. 66-92.

112 J. SANCHIS SIVERA, op. cit., 1924, pp. 21-22. Ampliado en M. GÓMEZ-FERRER LOZANO op. cit., 2009, pp. 15-16; esta autora considera que la maqueta representaba un modelo tridimensional en madera de todo el Real viejo.

113 Citado por J. SANCHIS SIVERA, op. cit., 1925, p. 42 y ampliado por M.M. SÁNCHEZ VERDUCH, "Maestros de obras en la Valencia gótica: personajes polifacéticos", Saitabi, 48 (1998), p. 278.

114 B. METGE y A. TURMEDA, Obres menors, Barcelona, 1927, pp. 110-111. 
que perduraría durante siglos desde la ciudad, la ribera del Turia y el Llano del Real, que vino a acomodarse a la imagen icónica del palacio para la arquitectura valenciana hasta el ocaso medieval. A ella se conformaron, en cierto modo, la fachada principal de la Casa de la Ciudad a la calle de las Cortes, con sus dos torres angulares unidas por una galería alta o porche sobre la Sala de Consell, la vecina Casa de la Diputación del General o palau de la Generalitat y la misma Lonja de mercaderes, al incorporar un torreón entre el pabellón del Consulado del Mar y la gran sala de contratación, que no puede dejar de evocar la torre alzada sobre la Cámara de los Ángeles en el Real $^{115}$. Éste en realidad conjugaba la imagen de la fachada pétrea con ventanas de columnillas y acceso entre dos grandes torres heredada de tiempos de Pedro IV el Ceremonioso con el cuadrilátero torreado que había reformado Alfonso V el Magnánimo, llamado a convertirse en modelo de otras residencias señoriales valencianas a fines del siglo XV como el palacio de los Berenguer d'Aguilar en Alaquàs, el palacio condal de Oliva de la familia Centelles, el palacio de los Próxita en Llutxent o el de los Sorell en Albalat dels Sorells ${ }^{116}$.

El propio rey se preocupó por la visibilidad del palacio desde la ciudad en el contexto de renovación de su aspecto exterior al ordenar en octubre de 1427 el derribo de un huerto vecino per embelliment del dit Real per tant com empatxave la vista del dit Real, lo que acarreó también el desarraigo de los árboles que allí estaban plantados. Contaba también con la vista que se tenía desde los apartamentos reales, pues el monarca quería que tot allò fos plaça tant com era l'enfront de les cambres o partida qui respon vers la dita rambla on posa la senyora Reyna, per çò que lo dit enfront se mostràs pus bell e haguès major vista per mirar lo dit Real ${ }^{117}$. Así se abría una diáfana extensión delante del acceso principal del palacio, comunicado con la ciudad por uno de los cinco puentes sobre el Turia, que específicamente debía enlazar la residencia real con la de su última morada, en el panteón dispuesto en un principio en la capilla de los Reyes del convento de Santo Domingo, ya entonces con una plaza también de forma irregular y capaz de albergar actos multitudinarios ${ }^{118}$. Es posible que esta explanada sirviese como espacio para visualizar al monarca ante la fachada del palacio, considerando el uso celebrativo y festivo que registran reiteradamente las fuentes, pero a partir de finales del siglo XV su atractivo menguó a favor de la fachada posterior y de sus amenos jardines, admirados por viajeros y cronistas, cuya

\footnotetext{
115 Sobre la sede valenciana de la Diputación del General, véase S. ALDANA FERNÁNDEZ, El Palacio de la "Generalitat" de Valencia, Valencia, 1992; acerca de la Lonja de mercaderes, F. IBORRA BERNAD y V. GARCÍA ROS, "La Lonja que no fue. Reflexiones e hipótesis a propósito del proyecto inicial de la Lonja de Valencia", Anales de Historia del Arte, 22 número extraordinario (2012), pp. 295-315, en particular, pp. 305-312.

116 A propósito véase L. ARCINIEGA GARCÍA, El palau dels Borja a València, València, 2003, pp. 141155; sobre la sala del Real viejo como parte de un proyecto de nueva fachada para ese sector del conjunto, $\mathrm{M}$. GÓMEZ-FERRER, op. cit., 2012, p. 81.

117 ARV, Mestre Racional, registro 9134, f. 1r-2r; citado por J.V. GARCÍA MARSILLA, op. cit., 19961997, en especial, pp. 36-37. La misma noticia a través de otra fuente en J.L. CORBÍN FERRER, Desde los Jardines del Real a la plaza de Tetuán, su entorno y su historia, Valencia, 1985, p. 68.

118 Sobre la capilla real en el convento de santo Domingo, A. ZARAGOZÁ, L. TOLOSA y M.C. VEDREÑO, La capella reial d'Alfons el Magnànim a l'antic convent de Predicadors de València, València, 1997.
} 
extensión y cuidado creció al ritmo de las reformas de los apartamentos durante el reinado del Magnánimo y María de Castilla ${ }^{119}$. Allí se hallaban además de los establos y caballerizas, vergeles, huertos y animales raros como los leones, asociados desde antiguo al poder monárquico como los leones o los pavos reales, que Pedro el Ceremonioso consideraba abelliments de grans cases e plaers de senyors ${ }^{120}$.

\section{La corte y la ciudad: la fiesta cívica y el Real}

La principal fiesta cívica en Valencia era la entrada real, motivada por la recepción del monarca, su esposa y el primogénito, si bien se asimilaron a ella las celebraciones con que se agasajaba a grandes prelados como el papa Benedicto XIII en 1414 o el cardenal Rodrigo de Borja en $1472^{121}$. Aunque ajena al ciclo anual de solemnidades, la entrada real estaba vinculada a ellas y formaba con el Corpus Christi el díptico de las grandes celebraciones urbanas. La primera visita a Valencia del rey, la reina o del heredero del trono se festejaba, tras la bienvenida en un portal de la muralla, con una cabalgata bajo palio por el itinerario establecido para la procesión del Corpus Christi y otras ocasiones semejantes, el homenaje de las corporaciones de oficio en forma de danzas, juegos y entremeses, la entrega de una vajilla de plata como presente oficial del municipio, y la jura solemne de los fueros en la catedral, para terminar en el palacio del Real. Antes del llegar a su residencia, el monarca atravesaba las puertas de Serranos y del Temple, engalanadas para la ocasión y brillantemente iluminadas en el cielo nocturno. Tras la procesión de entrada, en los días siguientes se montaban

119 P. DE INSAUSTI MACHINANDIARENA, Los jardines del Real de Valencia. Origen y plenitud, Valencia 1993, en especial, pp. 29-69; M. GÓMEZ-FERRER, op. cit., 2012, pp. 251-265 para los jardines en época medieval.

120 J. RUBIÓ BALAGUER, op. cit., 1985, pp. 112-126; noticias sobre la custodia de estos animales en palacios de la Corona de Aragón han sido recogidas por diversos autores como A.M. ADROER I TASIS, "Animals exòtics als palaus reials de Barcelona", Medievalia, 8 (1988), pp. 9-22; y "La posessió de lleons, símbol de poder", XV Congreso de Historia de la Corona de Aragón, Zaragoza, 1996, Tomo I, vol. 2, pp. 257268; A. BLASCO MARTÍNEZ, "La casa de fieras de la Aljafería de Zaragoza y los judíos", XV Congreso de Historia de la Corona de Aragón, Zaragoza, 1996, Tomo I, vol. 2, p. 291-318; y H. BORJA, op. cit., 2002, pp. 73-78.

121 S. CARRERES ZACARÉS, op. cit., 1925 dio a conocer las principales fuentes y ofreció un panorama de amplia cronología; a este libro han seguido los trabajos modernos de J. OLEZA, "Las transformaciones del fasto medieval", Teatro y espectáculo en la Edad Media. Actas del Festival d'Elx 1990, Alicante, 1992, pp. 47-64; T. FERRER VALLS, "El espectáculo profano en la Edad Media: espacio escénico y escenografía", Historias y ficciones. Coloquio sobre la literatura del siglo XV, Valencia, 1992, pp. 307- 322; y "La fiesta cívica en la ciudad de Valencia en el siglo XV", Cultura y representación en la Edad Media. Actas del II Festival de Teatre i Música Medieval (Elche, 28 de octubre-1 de noviembre de 1992), Alicante, 1994, pp. 145169, M. FALOMIR, Arte en Valencia, 1472-1522, Valencia, 1996, pp. 397-415, es probablemente el primer historiador del arte que se ocupó de la fiesta cívica medieval; V. ADELANTADO SORIANO, "Una consueta del siglo XV", Lemir. Revista electrónica de Literatura Española Medieval y del Renacimiento, 8 (2004), http://parnaseo.uv.es/Lemir/Revista/Revista8/Adelantado.pdf [consultado el 25/04/2013]; R. NARBONA VIZCAÍNO, Memorias de la Ciudad. Ceremonias, creencias y costumbres en la historia de Valencia, Valencia, 2003, pp. 85-100; y F. MASSIP, A cos de rei. Festa cívica i espectacle del poder reial a la Corona d'Aragó, Valls, 2010, en especial, pp. 25-147. 
palenques y entablados en la Rambla, ante la fachada del Real ${ }^{122}$. Las luminarias y los fuegos de artificio del Real se unían al festejo, con las luces y ahumadas en el cimborrio y en el campanario de la catedral así como en otras torres de las puertas y la muralla de la ciudad, en festividades periódicas y eventos como las visitas reales o victorias militares. En las torres del Real se alzaban estandartes para festejar la llegada del monarca y señalizar su presencia en Valencia, como se hizo en 1424 con Alfonso el Magnánimo, en 1458 por la venida de Juan II y, de nuevo, en 1472, 1479 y 1481 para celebrar la visitas de Fernando II de Aragón, como príncipe primero y luego como rey ${ }^{123}$. El control de esta ceremonia de recepción urbana estaba en manos de los regidores de la ciudad, al programar los actos y el orden de la comitiva de acuerdo con intereses que combinaran las muestras de fidelidad con la afirmación de un orgulloso patriotismo urbano ${ }^{124}$.

En estas ocasiones Valencia entera se transfiguraba en escenario efímero para agasajar al monarca y reforzar los vínculos entre el poder municipal y la autoridad real: las calles se cubrían con mirto y otras plantas aromáticas, de las casas y edificios públicos colgaban paños y tapices en honor de los visitantes regios, parte del trayecto se protegía con envelados de la intemperie y la carrera había sido desembarazada de inmundicias y obstáculos, aun a costa de derribos y ensanches de vías públicas. Los participantes en la ceremonia vestían ese día de gala para representar a los diversos oficios de la menestralía, a las autoridades de la ciudad y a los estamentos que formaban jerárquicamente la comunidad de ciudadanos, pero también se disfrazaban con un colorido y un fasto que contribuían a transformar el aspecto de las gentes en sintonía con la apariencia singular de la ciudad en aquella fiesta.

Desde la segunda mitad del siglo XIV el cortejo iba precedido y acompañado de representaciones lúdicas, música, bailes, entremeses y comparsas que rendían homenaje y divertían al visitante real, desde el lugar de la bienvenida extramuros y a lo largo de todo el recorrido por las calles de Valencia. La descripción conservada del ceremonial de la entrada en 1373 de Mata de Armañac, esposa del entonces infante Juan, refleja un alarde de música, animación y fantasía en los entremeses preparados para la ocasión ${ }^{125}$. Toma de castillos, luchas con dragones, batallas de naranjas y combates de galeras fueron parte del espectáculo de aquel día. Para la entrada real de Juan I en 1392 se convocó a todos los juglares que se pudiera encontrar y se introdujeron cambios en el ceremonial, al incorporarse el entremés de los armeros con una nau ab serenes e de una rocha sobre carros, confeccionados a petición de los Jurados por el pintor Domingo de la Rambla y el armero Berenguer Romeu, como mayorales del

122 S. CARRERES ZACARÉS, op. cit., 1925, I, pp. 42-43 y II, pp. 57-63; T. FERRER VALLS op. cit., 1994, pp. 145-169.

123 La llegada de Alfonso V se esperaba por mar a finales del año 1423, pero se retrasó hasta febrero del año siguiente y fue por tierra, a través del portal de Serranos. S. CARRERES ZACARÉS, op. cit., 1925, I, pp. 65-69; II, pp. 96-109 (entrada de Alfonso el Magnánimo); I, pp. 73-77; II, pp. 115-128; (entrada de Juan II); I, p. 87-94 (visitas del príncipe y luego rey Fernando el Católico); M. GÓMEZ-FERRER, op. cit., 2012, pp. 66,93 у 95 .

124 V. ADELANTADO SORIANO, op. cit., 2004; M. RAUFAST CHICO, “¿Negociar la entrada del rey? La entrada real de Juan II en Barcelona (1458)", Anuario de Estudios Medievales, 36/1 (2006), pp. $295-333$.

125 S. CARRERES ZACARÉS, op. cit., 1925, I, pp. 33-38; II, pp. 28-31. 
oficio de $\operatorname{armeros}^{126}$. El recorrido en aquella ocasión se estableció que "girase por la calle que va hacia las Cortes y pase delante de aquéllas y delante de la Sala del Consell y [siga] por la plaza hasta la puerta de la catedral" ${ }^{127}$. Ante el Real se montó un palenque para las justas cuyos adornos todos debían ostentar a señal del senyor Rey e de la senyora Reyna, y en la rambla un bell e alt taulat, para que los actos de júnyer $e$ de traure a taulat o los faents aquells nos puxen fer nosa ne torbar ${ }^{128}$.

El espectáculo ambulante de la comitiva por las vías principales de la ciudad con los cuadros vivientes que representaban los oficios, aumentó un grado más cuando se sumaron los carros triunfales o rocas y los entremeses que solían acompañar a la procesión del Corpus Christi, como sucedió por ver primera en la entrada de Martín I en $1402^{129}$. Un equipo variado de artífices se afanaron durante meses en las labores de montaje, figuración, pintura y dorado de esta maquinaria rodante y vivaz que debía deslumbrar a propios y extraños, de suerte que una partida cuantiosa del gasto correspondió a jornals de maestres d'axa, pintors, machinayres e altres qui feyen e endreçaven los dits jochs ${ }^{130}$.

Las imágenes en movimiento iban acompañadas a veces de recitaciones, mimos y siempre de la música festiva. Los juegos, danzas y pantomimas combinaban elementos profanos, festivos y burlescos en un espectáculo animado y repleto de figuraciones, donde se entremezclaban la imaginación caballeresca con la cultura popular; la parodia, con la coreografía ${ }^{131}$. En lo sucesivo se incrementó el gasto en la confección de nuevos entremeses y rocas a cargo de la hacienda municipal, concebidos para exaltar las cualidades del príncipe y las fuerzas sobrenaturales, dinásticas y territoriales que le asistían, como se pudo apreciar en la entrada real de Fernando I en 1414, que amplió el recorrido del cortejo e integró numerosos elementos de nueva factura y neto contenido político en su sentido alegórico y moral ${ }^{132}$. Este monarca había pedido al consejo municipal valenciano que le prestara para la coronación en Zaragoza las vestiduras y atuendos de ángeles que se empleaban en la procesión del Corpus, sellando así el entronque de las entradas reales con la procesión eucarística. El 14 de diciembre de 1414 la comitiva de recepción del papa Benedicto XIII siguió también el recorrido del Corpus Christi ${ }^{133}$.

126 A. RUBIO VELA (ed.), op. cit., 2003, p. 302; S. CARRERES ZACARÉS, op. cit., 1925, II, p. 64.

127 S. CARRERES ZACARÉS, op. cit., 1925, II, p. 57: giràs per los carrer qui va vers les Corts e passàs denant aquelles e denant la Sala del Consell e per la plaça tro a la porta de la Seu.

128 S. CARRERES ZACARÉS, op. cit., 1925, I, pp. 42-43; II, pp. 57-63.

$129 \mathrm{Se}$ incorporaron las rocas que escenificaban ex profeso entremeses y figuraciones costeados por el Consejo de la ciudad. La documentación ha sido publicada por J. ALIAGA, L. TOLOSA Y X. COMPANY (ed.), Documents de la pintura valenciana medieval i moderna II: Llibre de l'entrada del rei Martí I, Valencia, 2007. Véase también F. MASSIP, op. cit., 2010, pp. 73-95.

130 S. CARRERES ZACARÉS, op. cit., 1925, II, pp. 69-70.

131 R. NARBONA VIZCAÍNO, op. cit., 2003, pp. 139-142.

132 S. CARRERES ZACARÉS, op. cit., 1925, I, pp. 59-61, II, pp. 77-88; F. MASSIP BONET, "Imagen y espectáculo del poder real en la entronización de los Trastámara”, El poder real en la Corona de Aragón (siglos XIV-XVI). Actas del XV Congreso de Historia de la Corona de Aragón (Jaca, 1993), 5 vols., Zaragoza, 1996, III, pp. 371-386, en particular, pp. 381-385; F. MASSIP,op. cit., 2010, pp. 97-120.

133 J. MARTÍ I MESTRE (ed.), El Libre de Antiquitats de la Seu de València, 2 vols., Valencia, 1994, I, pp. 46-48; y S. CARRERES ZACARÉS, op. cit., 1925, I, pp. 61-63. 




Fig. 8. Frontispicio de la edición del Regiment de la cosa pública de Francesc Eiximenis (Valencia: Cristóbal Cofman, 1499).

La entrada real, y por extensión los cortejos de recepción de prelados y príncipes, tomaron prestados, pues, el itinerario y parte del espectáculo que acompañaba la procesión del Corpus Christi ${ }^{134}$. Celebrada anualmente diez días después de Pentecostés desde 1326 como solemnidad religiosa, estaba encabezada por el cabildo catedralicio y municipal, tomó plena carta de naturaleza en 1372, y doce años después siguió el recorrido que aún hoy se observa. Entonces el pregón o crida, la presentación oficial de los jurados al frente del consistorio y el conjunto de danzas, juegos, entremeses y rocas implicaban una representación colectiva de orgullo cívico y una afirmación de piedad pública que convertían Valencia en una ciudad ideal. La fiesta grande llegó a convertirse en una atracción para los forasteros y en una exhibición de la riqueza y el fasto ciudadanos. En 1393 asistieron a ella los reyes Juan I y Violante de Bar y en 1401 se retrasó unos días para que pudiera contemplarla la infanta Blanca de Navarra, esposa de Martín el Joven; en adelante no fue insólito que pudiera posponerse o repetirse en honor de los monarcas, como se hizo el 2 de agosto de 1427 per la devoció del Senyor Rey e Reyna dona Maria, com axi volguessen ${ }^{135}$. El 11 de diciembre de 1481, después de celebrar la procesión del Corpus con todas las rocas y entremeses,

134 M. CARBONERES, Relación y explicación histórica de la solemne procesión del Corpus que anualmente celebra la ciudad de Valencia, Valencia, 1873, incluye documentación referente a esta época; una revisión reciente en R. NARBONA VIZCAÍNO, "Apreciaciones históricas e historiográficas en torno a la fiesta del Corpus Christi de Valencia”, Revista d'història medieval, 10 (1999), pp. 371-382.

135 S. CARRERES ZACARÉS (ed.), op. cit., 1935, I, p. 509. 
los jurados invitaron a los Reyes Católicos a una espléndida colación en la Casa de la Ciudad. ${ }^{136}$

Novedades de todo tipo emergían en estos desfiles, en buena medida merced a la rivalidad entre ciudades por demostrar el alcance de su transformación en aras de un reconocimiento que traspasaba fronteras. De la impresión que estas ceremonias causaban en los espectadores coetáneos contamos con el testimonio indirecto del capellán de Alfonso el Magnánimo en 1428: e l'infant de Portogal e totes les sues gents estagueren admirades, e digueren que verdaerament crehiel que en tot lo huniversal món no y havia tal ciutat ${ }^{137}$.

En estos eventos la Casa de la Ciudad lucía con fulgor para tomar parte en la general transfiguración de Valencia en escenario festivo. En 1369 la reina Leonor de Sicilia presenció la procesión de san Dionisio desde la sala de la Casa de la Ciudad, decorada para la ocasión con draps d'or e de figures e ab neules pintades de papera ob de batifulles d'argent per via de cel en la dita sala. ${ }^{138} \mathrm{El} 4$ de enero de 1399 el nacimiento de un hijo de Martín el Joven, rey de Sicilia y llamado a ocupar su puesto en la línea de sucesión del trono, se celebró con gran alegría en Valencia: los regidores, consejeros y otras autoridades de la ciudad justats en la Sala del consell, ab gran multitut de ministrés, trompadors e altres jutglars de diverses esturments se sumaron con la bandera real a la procesión y ordenaron para el día siguiente que se pusieran luminarias en las torres de la Casa de la Ciudad e molts jutglars qui sonaven en aquelles, e en special en les torres de la Sala, demostran senyal de gran alegría. El cambio dinástico del Compromiso de Caspe (1412) fue festejado en la ciudad con el desfile de ministrers, jutglars e sonadors qui ab moltes e diverses sons de trompes, trompettes e nafils, tabals, caramelles, cornamuses e altres sturments de boqua e de corda anaren ${ }^{139}$. Estas fiestas, sus galas y las representaciones que discurrían en la ciudad pudieron dejar una huella más duradera en el ornato de dos edificios señeros de la ciudad. En el portal de Serranos la tracería ciega de arcos de tijera entre pináculos, labrada como una filigrana sobre la puerta, entre los escudos del rey y de la ciudad, recordaría con su policromía en grana y oro los palios y paños de raso con que se aderezaban los edificios en las grandes solemnidades, en sintonía con el remate coronado de las almenas originales. No es seguramente casual que éste fuera el acceso preferente a la ciudad en las ceremonias de entrada real y allí tuviera lugar la recepción y entrega de las llaves al monarca reinante o su heredero ${ }^{140}$. En otro plano, la prolija y caprichosa decoración del alfarje de la cambra daurada de la Casa de la Ciudad no nos parece ajena a los entremeses y a la animación de las cabalgatas que

136 S. CARRERES ZACARÉS, op. cit., 1925, I, p. 94.

137 M. MIRALLES, Crònica i dietari del Capellà d'Alfons el Magnànim, M. RODRIGO LIZONDO (ed.), Valencia, 2011, pp. 179-180.

138 S. CARRERES ZACARÉS, op. cit., 1925, I, pp. 31-32 y II, p. 16.

139 S. CARRERES ZACARÉS, op. cit., 1925, I, pp. 58-59 y II, p. 75.

140 Sobre la posible relación del énfasis monumental de los portales de Serranos y Quart con la entrada real, véase M. FALOMIR, Arte en Valencia, 1472-1522, cit., 1996, pp. 400-401; A. SERRA DESFILIS, "El portal de los Serranos en los siglos XIV y XV", F. CERVERA ARIAS y C. MILETO (eds.), Las Torres de Serranos. Historia y restauración, Valencia, 2003, pp. 11-26. 
acompañaban la fiesta cívica ya como recepción al monarca, ya en la procesión del Corpus Christi ${ }^{141}$

Al final del recorrido se alzaba el otro gran escenario: el Real con la explanada adyacente servía de telón de fondo a los banquetes preparados para lisonjear al monarca o a los más ilustres visitantes de la ciudad. En 1407 se celebró un torneo en la rambla, frente al Real, donde se construyó un entarimado por obra de los carpinteros de la ciudad Jaume de Monçó y Joan Rull, lo qual (...) fem fer de fusta semblant d'altres molts que per altres hic foren fets per veure, e retenir a memòria, en temps esdevenidor, armes de tota oltrança de batalles mortals concordades e empreses per valor de cavalleria entre don Pedro de Moncada y dos barones de Gascuña, en un bando, y el Senescal de Hainaut acompañado de dos caballeros franceses en el otro. Se alzó también un tablado entoldado para que el Rey y las autoridades de la ciudad y de otras contemplaran el torneo en $1407^{142}$. Para la entrada real de Fernando I en 1414, se alzaron entarimados en tres puntos de la ciudad en la rambla para ver las justas, en la plaza del mercado y delante del Real ${ }^{143}$. El huerto a las espaldas del Real se utilizó como lugar de celebraciones y campo de entrenamiento para las justas que se preparaban en honor del infante don Pedro de Portugal ${ }^{144}$, pero tenían más resonancia las fiestas y galas que se asomaban a la ciudad, desde la otra orilla del río, como el banquete ofrecido por Juan II en el Real a su yerno, el Conde de Foix, y a los embajadores de Francia, Génova y Provenza, para quienes el palacio se adornó espléndidamente con ricas colgaduras y muchas piezas de oro y plata en el tinell, congregando a tantos invitados que no cabien en lo dit Real ${ }^{145}$. El trueque de convites y agasajos entre la corte y la ciudad se repetía en cada entrada, en toda visita ilustre, en cualquier celebración, propiciando la emulación y la rivalidad entre el poder real y el ciudadano, entre el palacio del Real y la Casa de la Ciudad como escenarios preferentes de estos intercambios competitivos. Los artífices iban y venían de una a otra obra, cobraban su salario de las arcas reales y del erario municipal, como agentes de esta carrera por el ornato festivo y permanente de las grandes salas de representación, de las fachadas y de todo el aparato hoy casi olvidado de los estandartes y gualdrapas, las campanas y relojes mecánicos, los escudos y paveses pintados, los sellos y las vajillas.

141 A. SERRA DESFILIS y O. CALVÉ MASCARELL, op. cit., 2013, pp. 212-221.

142 S. CARRERES ZACARÉS, op. cit., 1925, I, pp. 57-58 y II, p. 74.

143 S. CARRERES ZACARÉS, op. cit., 1925, I, p. 59 y II, p. 81.

144 S. CARRERES ZACARÉS, op. cit., 1925, I, pp. 69-70.

145 S. CARRERES ZACARÉS, op. cit., 1925, I, p. 78; y M. MIRALLES, op. cit., 2011, pp. 267-269. 